\title{
Reducing Patient Risk for Suicidal Behaviors with a Safety Bundle of Best Practices with Non-Psychiatric Patients
}

Olayemi Akindele

University of St. Augustine for Health Sciences, o.akindele@usa.edu

DOI: https://doi.org/10.46409/sr.OFSB1999

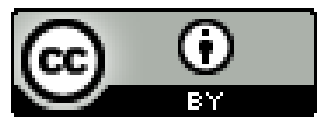

This work is licensed under a Creative Commons Attribution 4.0 License.

Follow this and additional works at: https://soar.usa.edu/scholprojects

Part of the Mental Disorders Commons, Other Psychiatry and Psychology Commons, Psychiatric and Mental Health Commons, and the Psychiatric and Mental Health Nursing Commons

\section{Recommended Citation}

Akindele, O. (2021). Reducing Patient Risk for Suicidal Behaviors with a Safety Bundle of Best Practices with Non-Psychiatric Patients. [Doctoral project, University of St Augustine for Health Sciences]. SOAR @ USA: Student Scholarly Projects Collection. https://doi.org/10.46409/sr.OFSB1999

This Scholarly Project is brought to you for free and open access by the Student Research at SOAR @ USA. It has been accepted for inclusion in Student Scholarly Projects by an authorized administrator of SOAR @ USA. For more information, please contact soar@usa.edu, erobinson@usa.edu. 
Reducing Patient Risk for Suicidal Behaviors with a Safety Bundle of Best Practices with Non-Psychiatric Patients

Olayemi C Akindele, MSN, RN, FNP-C, PMHNP-BC

School of Nursing, University of St. Augustine for Health Sciences

This Manuscript Partially Fulfills the Requirements for the

Doctor of Nursing Practice Program and is Approved by

Sheri Jacobson, PhD, RN

Rebekah L. Powers DNP, RN-BC, CMSRN, CSPHA, CHTS-CP

April 3, 2021 


\begin{abstract}
Practice Problem: Suicide is a public health condition that affects people globally. The increased suicidal behaviors of patients in a medical-surgical unit demanded an effective screening protocol to identify high-risk patients.

PICOT: In patients 18 years and older on a medical-surgical unit, does the implementation of the Columbia Suicide Severity Rating Scale (C-SSRS) tool and application of a Safety Bundle of Best Practices (SBBP) increase early identification of suicide risk with decreased patient selfharm behaviors, compared to the current standard practice of no assessment tool or safety bundle of best practices within 12 weeks?

Evidence: Ten studies served as evidence that assessment of early suicidal-risk behaviors decreased patient self-harm. The evidence supported the implementation of the C-SSRS tool and application of the Safety Bundle of Best Practices for the project intervention.
\end{abstract}

Intervention: The intervention consisted of three phases (pre-intervention, intervention, and post-intervention): a) patients were screened with the Columbia-Suicide Severity Rating Scale (C-SSRS); b) suicidal patients were managed with Collaborative Assessment and Management of Suicidality (CAMS); and c) a Safety Plan Intervention (SPI) was employed to manage suicidal behaviors.

Outcome: At the start of the assessment period, pre-intervention data yielded a C-SSRS risk score mean of 0.81 ; following the eight-week implementation period, post-intervention data yielded a C-SSRS risk score mean of 0.75 . There was a marginally significant difference between the means at pre- and post-intervention, showing a lower suicidal risk at postintervention, $p=0.07, t$-test result $(31)=1.87$. 
Conclusion: The decrease in patient self-harm behaviors with the implementation of the C-SSRS tool and application of SBBP was not statistically significant (SBBP). However, the decrease did indicate a clinically meaningful improvement in suicidal behavior outcomes after implementation of the intervention. 


\section{Reducing Patient Risk for Suicidal Behaviors with a Safety Protocol of Best Practices with Non-Psychiatric Patients}

The Coronavirus Disease (COVID-19) pandemic has illuminated the increased need for mental health services and suicide screening, especially in individuals who are immunocompromised, at higher risk for COVID-19 complications, or who are financially struggling. Suicide abruptly ends the lives of individuals while leaving friends, family, and colleagues to struggle with their grief and understanding of the situation (King et al., 2017). According to the Center for Disease Control and Prevention [CDC] (2018) over 42,000 individuals have committed suicide in the United States. The disease affects all ages and is the tenth leading cause of deaths in the U.S. (CDC, 2018).

Increasing suicide rates illuminate the need to optimize screening strategies to identify high-risk patients. Furthermore, it is recommended that multifactorial suicide-risk screening tools consider the specific needs of the individual person (King et al., 2017). Such recommendations include implementing suicide-risk screening in many healthcare settings, including primary care, medical specialties, and emergency departments (King et al., 2017). The purpose of this Doctor of Nursing Practice (DNP) project was to create a protocol for screening medical-surgical patients for suicide risk. The C-SSRS tool determined the suicide risk of the patient at admission to the unit; then SBBP was implemented based upon the risk assessment. The nursing staff documented in the Electronic Medical Record (EMR) when a patient was identified at risk and which SBBP interventions were implemented to maintain patient safety.

\section{Significance of the Practice Problem}

The practice problem addressed was that the facility has had a number of suicide attempts on non-psychiatric units and was cited by The Det Norske Veritas Accreditation for not having a 
protocol in place. Therefore, a need was identified for an evidence-based practice change to implement a protocol for nursing staff to screen medical-surgical patients for suicidal risk.

Suicide is described as the intentional taking of one's own life, a critical health problem that can have lifelong effects on family members and the community. Suicide is a global public health problem (Arensman et al., 2020). The effect of suicide is very disabling on loved ones and can cause long-term pain, depression, and decreased quality of life (Aquila et al., 2020). Suicide is not referred to as a mental illness but can be a symptom of several psychiatric disorders including schizophrenia, bipolar disorder, depression, and substance use disorder (Sadock \& Sadock, 2014). In 2018, suicides and suicide attempts cost the nation almost $\$ 70$ billion per year in medical and work-loss costs alone (CDC, 2020).

Globally, suicides are the second leading cause of untimely death in people aged 15 to 29 and the third leading cause of premature death in individuals $15-44$ years. The global rate is estimated to be $1.4 \%$, ranging from $0.5 \%$ in Africa to $1.9 \%$ in Southeast Asia (Bachmann, 2018). There has been a $6.7 \%$ increase in the total number of suicide deaths in the last 27 years, amounting to almost 817,000 deaths in 2016 (Naghavi, 2019). According to the World Health Organization (2020), almost 800,000 people die from suicide every year; the global annual mortality rate from suicide has been estimated to be 10.7 per 100,000 individuals.

Nationally, suicide is the 10th leading cause of death in the United States for all ages and can be caused by multiple factors, mental health disorders being the most common (CDC, 2018). Suicide is a huge cost to the economy of many countries including the United States. In the United States, the suicide rate increased by 35\% from 1999 to 2018 , which is the equivalent of going from 10.5 per 100,000 to 14.2 , an increase on average of about 1\% per year from 1999 to 
2006 and of $2 \%$ per year from 2006 through 2018 (CDC, 2020). There continues to be a steady rise of suicide rates despite national goals to decrease the rate in the United States (CDC, 2020).

Locally, suicide is rated as the 11 th leading cause of death in Texas and the third leading cause of death among individuals ages 15 to 24 with almost 30 hospitalizations for suicide attempts (Texas Facts, n.d). In Texas, the estimated medical costs of hospitalizations for suicide attempts average $\$ 8,849$ per individual or over $\$ 95.6$ million annually (Texas Facts, n.d). In 2014 , the financial implications of suicide in Texas was reported to be $\$ 4.264$ million in lifetime medical and work-loss costs (University of Texas, 2017).

Risk factors for suicide include all traumas and stresses that can alter the psychological wellbeing of an individual: mental illness, financial issues, family conflicts, chronic health conditions, war, sexual violence, grief, and bullying (Bachmann, 2018; Vasconcelos Neto et al., 2020). The ongoing pandemic has also generated more risk factors due to forced isolation, decreased social contacts, increased hospitalization, deaths of loved ones, the inability to visit in the hospital to say goodbye, and the inability to have funeral ceremonies (Aquilla et al., 2020).

Suicide is a known critical public health problem that can be prevented if warning signs are recognized and intervention is done promptly. Safety planning, an emerging evidence-based practice that is effective at reducing suicidal behaviors, is a top consideration which includes developing support and coping skills that individuals can rely on when thinking of suicide (Little, et al., 2018). The increased suicide rates locally, nationally, and globally show the need to consider optimizing screening methods to identify patients that are at high risk for suicide.

\section{PICOT Question}

The PICOT question that will guide the clinical question is as follows: P-Patients 18 years and older on a medical-surgical unit, I-Implementation of the Columbia Suicide Severity 
Rating Scale (C-SSRS) tool and application of a Safety Bundle of Best Practices, C-Compared to current standard practice (of no assessment tool and Safety Bundle of Best Practices), O-

Outcome: increased early identification of suicide risk with decreased patient self-harming behaviors, T- Twelve weeks.

PICOT Question: In patients 18 years and older on a medical-surgical unit, does the implementation of the Columbia Suicide Severity Rating Scale (C-SSRS) tool and application of a Safety Bundle of Best Practices (SBBP) increase early identification of suicide risk with decreased patient self-harm behaviors, compared to the current standard practice of no assessment tool or safety bundle of best practices within 12 weeks.

\section{Evidence-based Practice Framework and Change Theory}

The evidence-based change framework that was used for this project is the Iowa model of evidence-based practice. This model centers on the healthcare system as a whole to implement and guide practice decisions based on the best available research and evidence (Christenbery, 2017). A theoretical framework was used in providing a structure and design of reference for the project. Eric Havelock's model of planned change supports this scholarly project. Havelock formulated the planned change that expanded on Lewin's theory (Havelock, 1973). He proposed his change model on building a relationship, diagnosing the problem, gathering resources, choosing the solution, gaining acceptance, and maintaining the change (Havelock, 1973). Havelock emphasized that the initial step when planning a change is to establish a relationship with the system in need of change (Havelock, 1973).

The second step of change is diagnosing the problem. He described this stage as a period when the reason for change needs to be established (Havelock, 1973). Havelock described the third process as the period of acquiring resources for the change project once it has been decided 
upon (Havelock, 1973). The fourth stage occurs when a pathway of change is selected from available options and then implemented (Havelock, 1973). The fifth stage is establishing and accepting change. After the implementation of the change, it must be established and accepted by the organization since resistance to change may occur at this time (Havelock, 1973). The last stage is making sure that the change is successfully maintained (Havelock, 1973).

\section{Evidence Search Strategy}

The search strategy included an electronic search of digital databases of different scientific literatures related to the PICOT questions within the last five years. Databases that were used included the following: CINAHL $(n=540)$, ProQuest $(n=150)$, PubMed $(n=500)$, Medline $(n=380)$, EBSCOhost $(n=520)$, and Google Scholar $(n=800)$. The initial search yielded 2,520 articles, most of which were not relevant to the project. After duplicates were excluded, 575 articles relevant to the project topic were retrieved. Filters were applied, and 190 studies conducted in English were selected, excluding 385 articles. Among the 190 relevant articles retrieved, 58 were full-text articles screened for eligibility; 43 were excluded, leaving 15 articles.

The keywords used for the article search were safety, suicide, suicide screening, suicide prevention, suicide risk, deliberate self-harm and suicidal behaviors. A PRISMA diagram from the original template by Moher et al., (2009) was used to summarize the result (see Figure 1). Upon review of the articles, five were meta-analyses which were evaluated, using the Johns Hopkins evidence level, to be level I [grades A and B] (Hopkins Medicine, n. d.). Four of the articles were longitudinal, cohort studies, which were level 4 (grade C). One was an observational study assessed to be evidence level 6 (grade D).

\section{Evidence Search Results and Evaluation}


The search yielded 2,520 articles. Articles were limited to the five-year period 2015-2020, After a thorough search through several databases, critical appraisals were made to judge the clinical and statistical importance of the chosen articles. Several of the articles showed expert opinion. Databases search included: CINAHL ( $=540)$, ProQuest $(n=150)$, PubMed $(n=500)$, Medline ( $n=380)$, EBSCO host $(\mathrm{N}=450)$, and Google Scholar $(n=500)$. Duplicates were excluded, and 575 relevant articles were retrieved. Filters were used, 190 studies conducted in English within the last five years applicable to the project were chosen, 385 articles were ruled out. Filters included full texts, quantitative studies, and date range. Among the 190 relevant articles retrieved, screening was done, 58 full-text articles were eligible; 43 were excluded and this left 15 articles. The 15 articles were then organized and summarized for PICOT question.

The Johns Hopkins Nursing Evidence-Based Practice hierarchy method was used to determine the level of each article in analyzing the literature. Evidence hierarchy helps in locating and ranking evidence sources according to the strength of the evidence (Petrisor \& Bhandari, 2011). A seven-level hierarchy is shown in Appendix J. The evidence table (Appendix A) represents the different evidence levels for the selected articles. The PRISMA (Figure 1) is a format modified from the original template by Moher et al. (2009). Articles reviewed included eight systematic reviews, evaluated by applying the Johns Hopkins level 1 and were graded as As and Bs (Hopkins Medicine, n.d). The other nine articles reviewed were randomized and nonrandomized control studies of levels 1 and 11 with grades of As and Bs. There were also observational studies which were evidence level 111 and grade quality Bs in Appendix B

\section{Themes from the Evidence}

This section will offer the similarities and differences noted in evidence related to suicide, suicide screening, suicide attempt, suicidal behaviors, suicide prevention, and 
components of PICOT questions. Boudreaux et al. (2016) and Schmutte et al. (2020) found that those attempting suicide or who had suicidal ideation were more likely to receive a diagnosis of a mental disorder in emergency departments and to recieve follow-up mental care than were those who merely self-harmed in ways short of suicide. They further noted that the identification of risk was the first necessary step for preventing suicide. McCabe et al. (2018) emphasized that brief psychological interventions appear to be effective in reducing suicide and suicide attempts.

Katz et al. (2020) conducted a study to assess the association between self-reports of suicidal ideation and suicidal behavior using the C-SSRS. The study was done on Veterans Administration patients receiving mental health services. The rate of suicide attempts reported on the C-SSRS were higher than those documented in Veterans Health Administration (VHA) records through either SPAN or ICD-10 (Katz et al., 2020). The authors recommended the use of C-SSRS screening to help detect patients at early risk for suicidal behavior (Katz et al., 2020). Recommendation was made to always use clinical judgement when assessing patients and interpreting responses. The findings supported the predictive validity of C-SSRS and proved that it can be used to identify mental health patients who are at risk but have never been diagnosed.

The CAMS is an evidence-based clinical intervention that has significantly emerged over many years of clinical research (Jobes, 2012). CAMS is a unique therapeutic scheme that combines assessment and treatment planning between a patient experiencing suicidal thoughts and a clinician. Ellis et al. (2015) also explained that CAMS has been shown to be a therapeutic approach in decreasing suicidal ideation and death.

Stanley and Brown (2012) developed a set of safety plan interventions (SPI) that consisted of a written, prioritized list of coping strategies and sources of support that patients can use to prevent a suicidal crisis. The basic components of the SPI included the following: 
recognizing warning signs of an impending suicidal crisis; employing internal coping strategies; utilizing social contacts and social settings as a means of distraction from suicidal thoughts; utilizing family members or friends to help resolve the crisis; contacting mental health professionals or agencies; and restricting access to lethal means.

According to Little, Neufeld and Cole (2018), suicidal thoughts and attempts can be decreased and lives may be saved if health care providers add safety measures into patient care, which will include screening to identify at-risk patients for suicide in all health care settings.

\section{Practice Recommendations}

Suicide is a serious public health concern with over 800,000 deaths annually; the rates have increased nationwide with the increase in pandemic cases, making suicide prevention a global public health priority (McCabeet al., 2018). In response to the question that guided this project, the literature supported the use of early intervention through screening patients at all health care settings for suicide symptoms. McCabe et al. (2018) reported that one in four people who complete suicide have had an encounter with a health care practictioner within twelve months of their death. This suggested that early engagement and therapeutic intervention focusing on theories of suicidal behavior as well as ongoing follow up contacts might help identify and decrease the rate of suicide (McCabe et al., 2018).

There are practice recommendations guided by national guidelines developed by the U.S. Department of Veteran Affairs (2019), The Joint Commission (2019), National Action Alliance for Suicide Prevention [best practices] (2019), and Substance Abuse and Mental Health Services Administration (2019). The common practice orders for dealing with possible suicidal patients in medical-surgical settings are to identify suicide intent, to increase the safety measures for at-risk 
patients, to refer the patient for behavioral intervention, and to close the loop through phone call, text, or email within 48 hours of hospital discharge (The Joint Commission, 2019).

Based on the empirical literature and evidence noted, the following practice recommendations were implemented: educational intervention for patients to discuss the treatment, condition, and methods that was utilized to protect them. The nurse should provide both verbal and written information regarding crisis hotlines such as the National Alliance on Mental Illness and should assess the patient for making healthcare decisions. The second recommendation was for the facility to provide educational intervention for the nurses using the C-SSRS instrument, interactive role-play, and teach-back methods. The third was to provide safety planning (remove cords, move patients closer to nurses' station, discuss plans with family or support system, and call the physician while activating the behavior team). The fourth was that once the patient is discharged from the hospital to close the loop within 48 hours by calling, texting, or emailing the patient (The National Action Alliance for Suicide Prevention, 2018).

All the articles presented supported patient safety through the early identification of suicidal behaviors in all settings. The ten articles used for this section were levels I and II with grade As and Bs based on the John Hopkins evidence level and grade quality along with the mental health organizations [Hopkins Medicine, n.d.] (see Appendix A). Research supported that suicidal ideations and suicide attempts can be decreased if healthcare providers screen patients and identify suicidal behaviors during the initial encounter (Bolster et al., 2019). This recommendation, derived from the various sources of literature and mental health institutions, led to the selection of the interventions for the PICOT question based on substantial information to support its efficacy when using the safety bundles that included screening patients with CSSRS tool and using CAMS and SPI on patients that screen positive for suicidal behaviors. 
The evidence-based practice change was the creation of a protocol for the use of the CSSRS tool upon admission of patients to any medical-surgical unit and implementing CAMS and Safety Plan Interventions when patients are identified at risk. Sustainability consisted of an annual staff meeting and the development of medical-surgical department policies to include the protocol created for the DNP project to decrease suicidal risk for patients.

\section{Project Setting}

This evidence-based practice change project was conducted at a not-for-profit, westTexas hospital that serves Midland County and its surrounding region. It is the only hospital in Midland, Texas, and delivers care to pediatric, adult, and geriatric patients with medical or surgical needs. The hospital serves a diverse population that includes all of the cities that surround Midland, including urban, suburban and rural areas. The mission of the organization is to create an environment that supports the healing process and that improves the health and wellbeing of the community (Midland Health, 2020). The vision of the hospital is for Midland to be the healthiest community in Texas (Midland Health, 2020). The culture embraces a caring partnership, community outreach, and a care-delivery model of patient- and family-centered care. The organization meets the needs of a dynamic community, the organizational structure includes a president, vice president, and the board of directors who oversee the health board, executive team, and senior leadership (Midland Health, 2020).

A combination of best practices as found in the literature and a desire to decrease suicidal ideation and deaths established the organization's desire to implement the use of C-SSRS and the application of SBBP on non-psychiatric patients (R. Powers, personal communication, May 13, 2020). The evidence-based practice change was the creation of a protocol for the use of the CSSRS tool upon admission of patients to the medical-surgical unit, on every shift, and before 
discharge. The protocol also included implementing CAMS and Safety Plan Interventions when patients are identified at risk. Sustainability will consist of an annual staff meeting as well as the development of medical-surgical department policies to include the protocol created for the DNP project to decrease patient suicidal risk. There was strong evidence that the use of screening tools and the application of safety bundles results in detecting suicide ideation and decreasing suicide attempts (Appendix A). Organizational support was confirmed by personal communication with the Director of Patient Services (R. Powers, personal communication, May 13, 2020).

The stakeholders are the president, vice president, clinical director, education director, executive team, information technology, medical directors, nurses, preceptor, and this DNP student. The SWOT analysis can be used to plan the development of an organization and can also be used for a goal that requires strategic planning (Good, 2020). The strength of an organization includes internal factors such as financial resources, human resources, facilities, equipment, processes, and systems (Good, 2020). Weaknessess were factors that prevent the organization from achieving the stated goals. Opportunities were positive factors that influence the growth of the organization such as climate, market trends, environment, and funding (Good, 2020). Threats were issues that could hinder the development of the organization.

The strength of the organization included dedicated staff, teamwork, quality transparency, experienced providers, support from the leadership team, and improved medical technology. Weaknesses were a lack of screening protocols for patients at risk for suicide on the non-psychiatric unit and a lack of provider training regarding a standardized procedure for screening suicidal patients. Despite its excellent performance, the organization had opportunities for more growth such as educational advancement and the motivation of key stakeholders to implement the evidence-based project. 
The organization was faced with the threat of costs, time constraints, and the resistance to change by the staff. However, research showed that interprofessional collaboration can allow professionals from different fields to collaborate and provide high-quality care with the goal of decreasing cost, decreasing medical errors, and improving health (Hinrichs et al., 2020). Promoting collaboration among several healthcare providers is effective in managing comorbidities and in improving lives. Interprofessional collaboration is an important aspect of care delivery needed to accomplish excellent patient and system-level outcomes (AkuamoahBoatenget al., 2019). The DNP student facilitated terprofessional collaboration to positively impact the outcomes of the project. A SWOT analysis is provided in (Appendix I).

\section{Project Overview}

This evidence-based change project was to deliver care in connection with the hospital's mission and vision statement. The goal is to offer healthcare that is representative of the diversified community it serves. The mission for this project was to implement the use of the CSSRS tool and apply a SBBP on non-psychiatric patients to identify suicidal ideations and decrease suicide death. The vision for the project was to promote the lives of patients by working with the interprofessional team to provide patient-centered and high-quality safety measures for suicide prevention. Safety bundles included the use of CAMS and Safety Plan Interventions.

\section{Short-Term Objectives}

The hospital's short-term goal was to create a facility protocol of early identification of patient risk for suicide on the medical-surgical unit with the use of an evidence-based reliable and valid tool such as the C-SSRS and the implementation of a SBBP once a patient is deemed "at risk." The second goal was to prevent patient from any self-harm related to suicide attempts. The screening occurred during the second month of project implementation. Additional short- 
term goals included $100 \%$ nursing adherence in performing the screening utilizing the correct instrument and documentation. All nursing staff (registered nurses) completed the educational training within the first two weeks of implementing the project. The performance rates of conducting the suicide screening were measured by the numerator, which defines the desired action. The staff needed time to adjust to implementing a new task in their area. For this evidence-based practice change project, the overall short-term objectives were to increase the nursing staff's knowledge and implementation of suicide screening in non-psychiatric patients.

\section{Long-Term Objectives}

The long-term objective was to ensure the use of the screening tool by the nurses and the application of SBBP in identifying at-risk patients for suicidal behaviors during an inpatient stay in order to prevent incomplete and complete suicides. Currently, the hospital has had nine records of discharged patients who committed suicide in the last eighteen months (R. Powers, personal communication, May 13, 2020). The inpatients were tracked by reviewing their medical history and by making a weekly chart audit. Protocols that were implemented included screening all patients using the standardized, evidence-based suicide screening tool on admission; reviewing the patient's medical history on every shift; implementing the safety bundle on any patients that says yes to any question on the C-SSRS tool; and reviewing the screening questionnaires with the patient or patient's family before hospital discharge. For patients with a positive screening, the protocol included notifying the doctor and getting an order for one-on-one monitoring, removing all items that patient could use to harm self, and notifying the charge nurse and the behavioral team.

The behavioral team intervened by using CAMS and SPI as discussed in (Appendix F). 
Consistent screening promoted early suicide detection rates as the result of the project. The longterm goal included ensuring compliance with on-going annual training for the staff.

\section{Risks and Unintended Consequences}

For the participants that were screened positive for risk for suicide, the safety bundle was implemented and the behavioral team activated for a mental health professional to assess and create a plan of care for such patients. A few risks and unwanted consequences of the project included unwilling participants, non-buy-in from staff and nursing administration, resistance to change by the providers, increased time to implement the project because of unforeseen circumstances, and costs of educating staff. Additionally, risks involved were lack of reporting or documenting suicidal risk by the nurse and the subsequent lack of SBBP. The project manager and the charge nurses reviewed the C-SSRS assessment for follow-through of the protocol to promote patient safety. The Havelock's Theory of Change was used to create the change process.

\section{Project Plan (Method)}

The evidenced-based model that guided the development and implementation of the project is Havelock's theory of change (1973). The rationale for using this model was to help to thoroughly obtain and understand information for carrying out the evidence-based project and to improve patient outcomes. Havelock's Theory of Change builds on Lewin's change theory, which stated that there are two paths in examining stages of an intervention. The first path was to see things from the viewpoint of the individuals being changed, and the second path was to know the position of the person creating the change (Havelock, 1973). For many nurses, change was hard because most people prefer traditional methods (Kodama \& Fukahori, 2017). They prefer to continue using a method that has worked versus trying something new. The project manager was a change agent with four roles: catalyst, solution giver, process helper, and resource linker. 
This model summarizes three approaches for one to accept a change. The first was problem-solving, the second was social interaction, and the third was research development directed by five assumptions. The assumptions were the rationale for the change, planning, division of labor, passive consumer, and initial development costs (Havelock, 1973). Havelock's model utilizing change-agent roles, strategies, and assumptions has shown how an empowered staff could improve the quality of patient care by using the C-SSRS tool for medical-surgical unit patients. Havelock's model also offered a six-step sequence for staff adopting a new change intervention. The six steps included establishing a client relationship, establishing the need for change, securing the necessary resources, selecting the appropriate method, accepting and adapting the chosen strategy, and directing the individual in self-renewal (ability to change).

The project manager already established a relationship with the client system (as a nurse leader for the hospital). Interacting with the staff and nurse managers has allowed the project manager to develop positive relationships. The project manager enlisted viewpoints from the night and day shift nurses to help develop the project. The second phase is diagnosing the opportunity for change (Havelock, 1973). The project manager collaborated with the nurse manager, nurse liaison, and other disciplines for the input of ideas by brainstorming. The project manager considered the staff issues (strengths and weaknesses) related to patient care. In collaboration with the various individuals, the project manager was able to select the most appropriate strategy to implement suicide screening on the medical-surgical unit.

The resources used for the project were the nursing manager, nursing liason, patient safety manager, charge nurse, clinical manager, and nurse educator. The accepting and adapting phase use the chosen method of pre-intervention, intervention, and post-intervention as well as the suicidal screening tool as the method of implementation. The last stage involved the project 
manager guiding the staff into self-renewal ability to change (Havelock, 1973). The implementation of this project and sustainability led to staff empowerment and assimilation of change (Havelock, 1973). The project manager reassessed the project's effectiveness within two months of exceuting the project. During this time, the collaboration team assisted with orienting new nurses including students, new hires, and registry nurses.

The step-by-step method of how the project was implemented is as follows:

a. Hold initial meetings with interprofessional team members (preceptor, nurse manager, charge nurse, and administrators to gain support and approval for the DNP evidencebased practice change project.

b. Gain DNP project approval from the University of Saint Augustine School of Health Science EPRC committee.

c. Seek approval by the Institution prior to implementation of the DNP project (Key Stakeholders to gain support for the EBP project, the president, vice-president, nursing manager, nursing liaison, patient safety manager, charge nurse, clinical manager, and nurse educator).

d. Gain permission to use C-SSRS (See Appendix L).

e. Establish meeting (Zoom) with interprofessional team to propose budget for the project.

f. Approval of budget by the President and the Chief Financial Officer.

g. Perform pre-intervention chart review for comparison data, chart reviews of a minimum of 30 patients in medical-surgical unit.

h. Provide training and education for nurses on C-SSRS and Safety Bundle of Best Practices to include CAMS and SPI within the first two weeks of project implementation. 
i. Begin staff screening of all patients age 18 and up with C-SSRS tool for suicide risk upon admission to the medical-surgical unit.

j. Screening will continue to be performed by nurses on every shift; any patient that answers "yes" to any of the questions on the screening form will go through the intervention process, which is implementation of the Safety Bundle of Best Practices (CAMS and SPI). Behavioral team will be activated.

k. Remind all nurses that the Safety Bundle of Best Practices must be followed for each patient, the same way, every shift, and at discharge, collect data after seven days, two weeks, one month, and two months after implementation of intervention, perform data analysis and evaluation, and disseminate project results.

Patients identified at risk received the Safety Plan Intervention, part of the SBBP included obtaining order from provider to place patient on one-to-one monitoring and notifying behavioral team for mental health professional to assess the patient. The nursing staff checked patient environment and removed items such as cords, clothing, knives, metal, belts, shoelaces or anything that the patient could use to harm themselves. Additionally, the nursing staff initially met with patient and obtained permission to sit and talk, followed by encouraging patient to describe their psychological pain, stress, agitation, hopelessness, self-hate, and suicide risk. It is essential that nursing staff establish and document a plan to facilitate patient coping skills with current crisis. Nurses documented on paper and in the EMR if patients were assessed to be suicidal and if the SBBP was initiated.

A copy of paperwork was given to patient for the agreed upon Safety Plan. The additional Safety Plan Interventions included distraction, placing patient close to the nurse's station, and helping patient to explore resources for coping skills. The C-SSRS tool was in paper form. The 
nurses administered this form once every shift, at the end of which the forms were collected and submited to the charge nurses. The charge nurses gathered the forms and kept them in a locker in the nurse manager's office. Only the nurse manager and the charge nurses had access to the keys of the locker. The project manager collected the paper forms of the assessment for data analysis. Interprofessional Collaboration

Interprofessional collaboration is often defined within healthcare as an active and ongoing cooperation between professionals from diverse backgrounds with distinctive professional cultures working together to provide services for the benefit of all healthcare users (Morgan et al., 2015). In a healthcare organization, interprofessional collaboration allows different providers from diverse professional backgrounds to work closely together with patients, families, and communities with the main goal of providing quality care (Schot et al., 2020). The interprofessional collaboration for this project occurred face-to-face with the hospital manager, director, administration, and DNP preceptor bi-weekly at the conference hall of the organization.

\section{Budget}

The budget proposal was agreed upon by the team and finalized by the end of the fourth week. Table 4 shows the breakdown of the proposed budget.

\section{Data Collection}

Data collection and assessment began at one-week, one-month and two-month intervals to evaluate whether implemented changes have led to improved outcomes. A retrospective chart audit was conducted prior to the implementation of the intervention. A minimum of 30 charts were audited prior to intervention, and a minimum of 30 patients were in the sample for which intervention will be implemented. A form as shown in (Appendix G) was used to collect information for the chart audits and another form as shown in (Appendix D) for data collection 
after the implementation of the protocol to analyze results. The project manager used deidentifying methods to adhere to confidentiality procedures. The paper survey did not contain the participant's name, birthdate, or employee number. The de-identified code consisted of the first two letters of the participant's middle name with the last four digits of their cell phone number. There was no identifying data on any information obtained from the participants.

Data collection began with retrospective chart audits of the current-practice process of suicide risk assessment which consisted of asking the patient if they had suicidal ideation at admission as well as measures taken to protect the patient from harm, including monitoring through the use of a telemonitor (the telesitters are staff that continuously watch the patient's activities at the camera monitoring station). Data collected for the evidence-based practice change included the use of the CSSRS tool and the start of the SBBP when at-risk patients were identified. A data collection sheet tracked the patient by admission date, their responses to suicidal ideation, whether a monitor camera was used, and if the SBBP checklist was initiated.

\section{Project Timeline}

There was collaboration meetings among the chair, the DNP preceptor, and the project manager weekly or bi-weekly according to the development of the project. Interprofessional collaboration meetings occurred bi-weekly throughout the implementation of the project. Throughout the first weeks, several other meetings took place: the stakeholder's meeting, the budget proposal meeting, the Evidence-Based Practice Project Review Council (EPRC) submission meeting, and the meeting between the Nursing Chair and the DNP preceptor. Submission to the Nursing Research Review Board and Institutional Review Board (IRB) was completed by the third week for the approval of the project.

\section{Barriers and Facilitators}


Anticipated facilitators for these collaborations included brainstorming, administrative support, and supervised guidance by the DNP preceptor and chair. Barriers to the implementation of the project were assessed that could have been a delay in implementation due to the ongoing pandemic, lack of funds, or the nurses' resistance to change. The education and training for the nurses and staff took place between the third and the seventh weeks. A schedule of the evidence-based practice change is shown in (Appendix C). The expected benefits included administrative support, interprofessional collaboration and improved patient outcomes. Barriers included lack of funds to coordinate training of staff and resistance to change by the providers.

\section{Project Results}

The evidence-based project was evaluated by the outcome measures as described in the PICOT question. This section includes the data collection, data analysis, data storage, and data sources' integrity. Other segments comprised the integrity of the process, evaluation design, project setting and environment, comparison data, and how the intervention impacted the current use of suicidal screening. The last sections consist of HIPPA, recruitment process, participants, selection of participants, and how the project manager handled the missing data. The categories of measures discussed include outcome, process, balancing, finances, and sustainability.

The purpose of this evidence-based change project was to implement the use of the CSSRS tool (Appendix D) in identifying patients at risk for suicide upon admission to the medical-surgical unit and to initiate the SBBP when risk was identified, comparing the outcome to that of the current practice of simply asking patients if they have suicide ideation and documenting "Yes" or "No." The nurses screened all patients age 18 and older using the C-SSRS tool upon admission to the medical-surgical unit, at every shift, and at discharge. If "yes" was 
answered to any of the C-SSRS questions, an intervention process occurred utilizing the SBBP in (Appendix F) that comprised the CAMS and the SPI in managing suicidal behaviors.

Suicidal patients were assessed by the nursing staff, then received orders from the doctor to put the patient on one-on-one monitoring, activating the behavioral team. The behavioral team included the psychiatrist, medical doctor, registered nurses, charge nurse, and therapists. Any items such as cords, clothing, knives, metal, belts, shoelaces, or anything that patients could use to harm themselves were removed (Columbia University Department of Psychiatry, 2018). Compliance with the education and training was monitored by the facility's Director of Safety.

\section{Recruitment and Selection of Participants}

Recruitment and the selection of the participants began once the project manager received IRB approval from the university. All participants were informed that the project was voluntary. Informed consent by the participants was provided with a signature. The evidence-based project was conducted in a non-psychiatric (medical-surgical unit). A total of 32 patients participated in the evidence-based practice project. The inclusion criteria were any admitted adult patient ages 18 and above who stayed during the specified time. The exclusion criteria included individuals younger than 18 years and those diagnosed with mental illness or disability.

A chart audit of 32 patients was done dated back to two months prior with the form shown in (Appendix G); this was compared with the post-data after the implementation of the practice-change project. The rationale for collecting the pre- and post-intervention data was to determine whether the intervention made any impact on outcomes of the evidence-based project.

A purposive sampling was used because it was easy and convenient for the facility (Elil \& Negida, 2017). The sample size was met for the evidence-based project $(n=32)$. Other 
participants in the project were the Director of Patient Care, Director of Safety, and 15 full-time medical-surgical nurses who worked on the floor $7 \mathrm{am}-7 \mathrm{pm}$ and $7 \mathrm{pm}-7 \mathrm{am}$.

\section{Data Collection}

The project was implemented after obtaining permission from the University of St. Augustine for Health Sciences (USAHS) Evidence-Based Practice Review Council and the facility. Patients were given details about the project, and their consents were obtained before they participated in the project. Clinicians and nurses were given a questionnaire to assess their knowledge of and experience using the C-SSRS tool with education and training to use the tool.

The patient questionnaires were collected on every shift by the charge nurses that placed them inside a sealed envelope and securely transported them to the unit manager's office where they were placed in a locked file cabinet. The C-SSRS and the SBBP for each patient were deidentified using codes with numbers. Electronic data was kept on a Microsoft Excel 2016 spreadsheet and accessed using an encrypted computer password accessible only to project manager. Confidentiality measures were utilized per the university's IRB, hospital guidelines, and the Belmont Report. The questionnaires and any other data collected associated with the evidence-based project will be destroyed in three years per USAHS's protocol.

\section{Instrumentation and Permission to Use C-SSRS}

The C-SSRS is a questionnaire that was developed by Columbia University to assess for suicide; the protocol is evidence-supported and backed by the National Institute of Mental Health (NIMH). Appendix L houses the permission to use the tool which was granted on August 4, 2020, by Dr Posner. Appendix D shows the C-SSRS, a simple tool, clear and effective in preventing suicide as well as determining suicidal behavior in individuals. 
The CDC (2011) recommended the use of the C-SSRC tool for identifying suicidal behaviors in people of all ages (Columbia Lighthouse Project, 2016). The tool has attained detailed and accurate results by using rational, dependable, and science-based terminology in assessing suicidal behavior (Columbia Lighthouse Project, 2016). The C-SSRS tool provides six questions and checklists that help clinicians perform a detailed suicidal screening. The C-SSRC tool uses plain and direct language which is most suitable in eliciting honest and straightforward responses (Columbia Lighthouse Project, 2016). A five-item demographic questionnaire was used to collect information about the participants: gender, age, education, employment, and ethnicity. Descriptive statistics described the participants' characteristics and were used to analyze the data retrieved. The descriptive statistics consisted of the mean, median, and mode with the frequencies of categorical responses.

\section{Protection of Human Rights}

The DNP project proposal was submitted to and implementation approved by the EPRC review committee. Strict adherence was followed by using the Belmont Report to ensure the participants' protection and privacy. The C-SSRS and the SBBP for each patient were deidentified using codes consisting of the first two initials of the participant's middle name and the last four digits of the cell phone number (X: ST7736) and were kept in a locked file cabinet. Patient information was protected according to HIPPA guidelines. There were no conflicts of interest encountered or reported during the implementation of the project.

\section{Validity}

The validity of the C-SSRS tool has been determined by high sensitivity and specificity for suicidal behavior in comparison with other behavior scales and independent suicide evaluation boards (Posner et al., 2011). The validation of the tool was confirmed in three 
multisite studies conducted by Posner et al. (2011): a treatment study of adolescent suicide attempters $(n=124)$, a medication efficacy trial with depressed adolescents $(n=312)$; and a study of adults presenting to an emergency department for psychiatric reasons $(n=237)$. The C-SSRS tool shows good convergent and divergent validity with other multi-informant suicidal ideation and behavior scales (Posner et al., 2011).

\section{Reliability}

Reliability has been reported in many studies (Madan et al., 2016; Mundt et al., 2013; Na et al., 2018; Viguera et al., 2015; Youngstrom et al., 2015). The internal consistency of the tool is high with a Cronbach's alpha of 0.937 and 0.946 (Posner et al., 2011). Other studies such as Lindh et al. (2018) have used the tool and confirmed the reliability, and a literature review conducted by Conway et al. (2017) measured and validated its content. Matarazzo et al. (2018) confirm that the C-SSRS is a valid measure for suicide risk assessment.

\section{Data Analysis}

The questionnaire was given to the patient upon admission into the medical-surgical unit, every shift, and at discharge. A demographic survey was obtained from the EMR which includes the gender, age, ethnicity, employment, and level of education presented as ungrouped frequency distribution (Sylvia \& Terhaar, 2018). Descriptive statistics were used to analyze and document the selected population and the sample size (Leedy \& Ormrod, 2011). Categorical responses were used to analyze the mean, mode, and median (Sylvia \& Terhaar, 2018). A paired sample $t$ test was conducted to compare the C-SSRS data before and after the eight-week implementation period. The higher the C-SSRS risk score, the more likely a person is at risk of engaging in suicidal behavior. At the start of the assessment period, pre-intervention data yielded a C-SSRS risk score mean of .81; following the eight-week implementation period post-intervention data 
yielded a C-SSRS risk score mean of 0.75 (see Table 2). There was a marginally significant difference between the means at pre- and post-intervention, indicatining lower suicidal risk at post-intervention, $t(31)=1.87, p=0.07)$. These findings are documented in Table 3 .

\section{Paired Sample $t$-test}

A paired sample $t$-test was used to analyze the participant's risk for suicidal behavior upon admission and discharge from the hospital; this comprised the use of the C-SSRS tool by the admitting nurse and the discharge nurse on the unit. Statistical significance was defined as a $p$-value of less than 0.05 . The results of the answered questionnaires were compiled and saved using Microsoft Excel Spreadsheet (2016). Pearson's $r$ was used to determine the strength and direction of the relationship between the variables.

\section{Data Storage and Integrity}

The data was collected and analyzed by the project manager. Patient information was protected by strictly using de-identifying information. The hospital HIPPA policies were strictly adhered to in preventing loss of patient identifiers and maintaining confidentiality procedures. The hard copies of any C-SSRS assessments, the patient's SBBP plan, and data collection documents were kept in a locked file cabinet in the nurse manager's office to ensure privacy. The documents will be destroyed at the required time per USAHS's protocol.

\section{Handling of Missing Data}

Missing data is described as the information that is not stored in a variable of interest; this can threaten the validity of the project and reduce statistical power (Kang, 2013). The project manager handled missing data by narrowing down data collection to those who participated in the project. Two charge nurses (one day and one night shift) assisted with the data collection to prevent missing data (Kang, 2013). To ensure the evidence-based project's validity, the nurse 
manager and the project manager conducted a chart audit of the electronic medical records four weeks prior- and post-implementation. Any participant who had over $50 \%$ of the preintervention/post-intervention test information was not used in the project.

\section{Data Security}

Data was safely stored in a locked cabinet in the office of the Director of Patient Care and only the project manager had access to the keys. Necessary information will be destroyed after use according to the University's protocol. The project manager's laptop is company-issued and maintained in a locked office accessible only to the project manager. The documents will be destroyed at the required time per USAHS's protocol. Data will be erased from the laptop using ERASER software and hard copies will be placed in a Shred-It container at Staples.

\section{Process and Outcomes Measures}

The outcomes evaluated are decreased suicidal ideation and suicidal behaviors in nonpsychiatric patients as these outcomes are important in addressing the practice problem. A preintervention chart review of 32 patients in a medical-surgical unit was made dating back to two months before implementing the project for comparison data. Screening was conducted on patients by administering the C-SSRS questionnaire upon admission into the medical-surgical unit and telemetry unit. The C-SSRS tool was administered on every shift and at discharge. Data was collected and analyzed, and the approaches that were used to determine the success of the project and whether the outcomes were related to the interventions were the selection of quality measures and utilization of appropriate statistical analysis to compare baseline data to data collected after implementation of interventions (Sylvia \& Terhaar, 2018).

Training and education were provided to the nurses on how to use the screening tool; this included how to implement the safety bundle on patients identified at risk for suicidal behaviors. 
The project manager created a compliance checklist as shown in (Appendix E) that identified the non-compliant nurses. The Director of Patient Care frequently reminded the nurses to use the tool with the safety bundle effectively. Education on the use of the C-SSRS and the safety bundle was done weekly and bi-weekly for the first four weeks of the intervention on both shifts.

Process measures included nurses' and clinicians' compliance with using the C-SSRS as a first-line screening tool upon patient arrival into the non-psychiatric unit; nurses' and providers' compliance with education and training on the use of C-SSRS tool; clinicians' and nurses' compliance with timely administration of C-SSRS upon patient arrival to the unit; nurses' and clinicians' compliance with the use of safety bundles (Appendix G). Balancing measures included ensuring that suicidal ideations were identified and that suicidal behaviors do not increase throughout patients' stay in the non-psychiatric unit. Financial measures included the cost of providing training, education, and overtime cost due to training. The sustainability measures include on-going education and training of nurses and clinicians, compliance with the use of the screening tool in identifying at-risk patients, and early assessment of suicidal behavior.

\section{Outcome Measures}

The CSSRS Tool helped to identify patients at risk for suicide, telemonitoring assisted with decreasing the risk of patient self-harm, and the Safety Bundle of Best Practices initiated for at-risk patients decreased the risk for patients at risk for self-harm.

\section{Benchmarks}

The three benchmarks met were $100 \%$ of CSSRS screening for the patient at risk for suicidal ideation by the nursing staff, $100 \%$ of appropriate patients placed on telemonitoring by the nursing staff, and 100\% nursing staff initiation of Safety Bundle of Best Practices with documentation of which safety practice was implemented for the patient. 


\section{Impact}

Suicide is a public health issue that affects people locally, nationally, and globally. The impact of suicide causes a great deal of pain, depression, impairment, and poor quality of life in loved ones left behind (Aquila et al., 2020). Suicide can be a serious symptom of several mental illnesses including depression, bipolar disorder, schizophrenia, and substance abuse. Adequate screening is important to detect suicidal ideations and to prevent suicidal behaviors (Sadock \& Sadock, 2014). This project's primary outcome showed that the implementation of C-SSRS and the SBBP on the non-psychiatric unit decreased suicidal behaviors and deaths.

The clinical findings suggested that there was a marginal difference between suicide risk among medical-surgical patients following the eight-week period of implementation of the CSSRS, such that suicide risk only appeared to decrease. However, since pre-intervention data revealed that the mean score for suicide risk collected eight weeks prior to implementation was higher than the mean eight weeks after the implementation, it can be inferred that suicide risk decreased over time. It shows promise for a clinical significant implication for a practice change. Plans are underway to include the C-SSRS tool in the electronic health record of the facility site.

\section{Limitations of the Project}

During the planning and the implementation phase, some limitations were encountered. Limitations define the restrictions or constraints beyond an individual's control (Simon \& Goes, 2011). One of the limitations encountered was the small sample size, which was limited to the medical-surgical unit. The sample size was $32(n=32)$, with females, $n=15$; males, $n=17$, resulting in a lack of sufficient power, a condition known as "underpowered." It was noted that the small sample size did not validate the outcome of the project. A larger sample would have 
allowed more evaluation of the data, improved the data accuracy, preventing potential errors and limiting bias (Leedy \& Ormrod, 2011).

Another limitation was not having sufficient time to carry out the implementation; eight weeks was a short time frame and the changes brought about by the COVID-19 pandemic. Many nurses had left to care for their loved ones with Covid-19, the limited nurses were rotating to other departments, the facility had to rely on travel nurses who focused more on ensuring patient safety and reducing deaths. The shortage of staff and limited leadership support made it difficult for some of the nurses to participate in the project.

The use of the C-SSRS tool in (Appendix D) and the SBBP in identifying patients at risk for suicide upon admission to the medical-surgical unit is very important in decreasing suicidal ideations and behaviors (Ellis et al., 2015). The project has altered practice and addressed the practice problem of not having a protocol in place for nursing staff to screen medical-surgical patients for suicidal risk. Nurses and clinicians are now aware of the importance of adequately screening patients for suicidal behaviors at every shift. The future implications of the project include the continuous use of the C-SSRS and the SBBP by the nursing staff on the medicalsurgical unit to decrease suicidal behavior.

There needs to be continuous education and training of clinicians and nurses to maintain the sustainability of the intervention over time. Incorporating the screening tool in the EMR of the facility for daily monitoring of patients on the non-psychiatric unit in identifying suicidal behavior will ensure an ongoing evaluation of effectiveness.

\section{Plans for Dissemination}

The development of a dissemination plan is an essential component of an evidence-based process (Edwards, 2015). A 40-minute PowerPoint presentation of the project findings was given 
for the stakeholders, allowing feedback from everyone; members that couldn't attend were encouraged to watch the presentation through Zoom. The project findings will also be disseminated through a PowerPoint presentation at the Summer, 2021, Texas Association of Psychiatric Nurse Practitioner conference in Dallas, Texas, and at the American Psychiatric Nurses Association West Texas region. The Journal of American Psychiatric Nurses Association, which is a peer-reviewed journal and the largest resource for psychiatric-mental health and preventive nursing, has been selected for publication.

\section{Conclusion}

The Center for Disease Control and Prevention, (2018) has emphasized the increased suicide rates within the last decade. The need for suicidal screening has intensified with the COVID-19 pandemic and its financial and emotional obstacles. This project has illuminated the need to improve screening approaches in identifying high-risk individuals. Utilizing a multipurpose suicide-risk screening instrument allows a healthcare provider to better identify such persons (King et al., 2017). This project helped identify opportunities for improving and implementing policies that can be used for high-risk suicidal medical-surgical patients. Early detection is an essential part of the prevention strategy, and many individuals who commit suicide visit a healthcare provider months before their demise (NIMH, 2020). Practitioners must seize opportunities to identify individuals at risk and to connect them with the best available mental health resources. 


\section{References}

Ahmedani, B. K., Simon, G. E., Stewart, C., Beck, A., Waitzfelder, B. E., Rossom, R., Lynch, F., Owen-Smith, A., Hunkeler, E. M., Whiteside, U., Operskalski, B. H., Coffey, M. J., \& Solberg, L. I. (2014). Health care contacts in the year before suicide death. Journal of General Internal Medicine, 29(6), 870-877. https://doi.org/10.1007/s1 1606-014-2767-3

Akuamoah-Boateng, K. A., Wiencek, C., Esquivel, J. H., DeGennaro, G., Torres, B., \& Whelan, J. F. (2019). RAMPED-UP: The development and testing of an interprofessional collaboration model. Journal of Trauma Nursing, 26(6), 281-289. https://doi.org/10.1097/JTN.0000000000000466

Aquila, I., Sacco, M. A., Ricci, C., Gratteri, S., Montebianco Abenavoli, L., Oliva, A., \& Ricci, P. (2020). The role of the COVID-19 pandemic as a risk factor for suicide: What is its impact on the public mental health state today? Psychological Trauma: Theory, Research, Practice, and Policy, 12(S1), S120-S122. https://doi.org/10.1037/tra0000616

Arensman, E., Scott, V., De Leo, D., \& Pirkis, J. (2020). Suicide and suicide prevention from a global perspective. Crisis, 41(Suppl. 1), S3-S7. http://dx.doi.org/10.1027/02275910/a000664

Bachmann S. (2018). Epidemiology of suicide and the psychiatric perspective. International Journal of Environmental Research and Public Health, 15(7), 1425. https://doi.org/10.3390/ijerph15071425

Boudreaux, E. D., Jr.Camargo, C. A., Arias, S. A., Sullivan, A. F., Allen, M. H., Goldstein, A. B., Manton, A. P., Espinola, J. A., Miller, I. W., \& Camargo, C. A., Jr. (2016). Improving suicide sisk screening and detection in the emergency department. American Journal of Preventive Medicine, 50(4), 445-453. 
Brodsky, B. S., Spruch-Feiner, A., \& Stanley, B. (2018). The Zero Suicide Model: Applying evidence-based suicide prevention practices to clinical care. Frontiers in Psychiatry, 9, 33. https://doi.org/10.3389/fpsyt.2018.00033

Burnes, B. (2020). The origins of Lewin's three-step model of change. Journal of Applied Behavioral Science, 56(1), 32-59. https://doi.org/10.1177/0021886319892685

Center for Disease Control and Prevention. (2020). Increase in suicide mortality in the United States, 1999-2018. https://www.cdc.gov/nchs/products/databriefs/db362.htm

Center for Disease Control and Prevention. (2018). Suicide across the United States. https://www.cdc.gov/vitalsigns/suicide/index.html

Centers for Disease Control and Prevention. (2015). Youth risk behavior surveillance-United States. Morbidity and Mortality Weekly Report, 65(6), 1-174.

https://www.cdc.gov/healthyyouth/data/yrbs/pdf/2015/ss6506_updated.pdf

Center for Disease Control and Prevention. (2020). Preventing suicide. https://www.cdc.gov/violenceprevention/suicide/fastfact.html

Christenbery, T.L. (2017). Appendix:Evidence based practice models. Springer. https://connect.springerpub.com/content/book/978-0-8261-2759-4/backmatter/bmatter1?implicit-login=true

Columbia University Department of Psychiatry. (2018, June). Identification, triage, and monitoring using the Columbia suicide severity rating scale [PowerPoint slides]. http://vtspc.org/wp-content/uploads/2018/06/Lesser_Full-C-SSRS-TrainingVermont.pdf

Conway, P. M., Erlangsen, A., Teasdale, T. W., Jakobsen, I. S., \& Larsen, K. J. (2017). Predictive validity of the Columbia-Suicide Severity Rating Scale for short-term suicidal 
behavior: A Danish study of adolescents at a high risk of suicide. Archives of Suicide Research: Official Journal of the International Academy for Suicide Research, 21(3), 455-469. https://doi.org/10.1080/13811118.2016.1222318

Drapeau, C. W., Nadorff, M. R., McCall, W. V., Titus, C. E., Barclay, N., \& Payne, A. (2019). Screening for suicide risk in adult sleep patients. Sleep Medicine Reviews, 46, 17-26. https://doi.org/10.1016/j.smrv.2019.03.009

Edwards, D. (2015). Dissemination of research results: On the path to practice change. Canadian Journal of Hospital Pharmacy, 68(6), 465-469. https://doi.org/10.4212/cjhp.v68i6.1503

Elfil, M., \& Negida, A. (2017). Sampling methods in clinical research: An educational review. Emergency, 5(1). https://doi.org/10.22037/aaem.v5i1.177

Ellis, T. E., Rufino, K. A., Allen, J. G., Fowler, J. C., \& Jobes, D. A. (2015). Impact of a suicidespecific intervention within inpatient psychiatric care: The Collaborative Assessment and Management of Suicidality. Suicide \& Life-Threatening Behavior, 45(5), 556-566. https://doi.org/10.1111/sltb.12151

Ettorchi-Tardy, A., Levif, M., \& Michel, P. (2012). Benchmarking: A method for continuous practice change in health. Healthcare Policy, 7(4), e101-e119. https://www.ncbi.nlm.nih.gov/pmc/articles/PMC3359088/

Good, C. (2020). Plot your next move with a SWOT analysis. MGMA Connection, 128-129. Gould, C., McGeorge, T., \& Slade, K. (2018). Suicide screening tools for use in incarcerated offenders: A systematic review. Archives of Suicide Research : Official Journal of the International Academy for Suicide Research, 22(3), 345-364. 
Grumet, J. G., Hogan, M. F., Chu, A., Covington, D. W., \& Johnson, K. E. (2019). Compliance standards pave the way for reducing suicide in health care systems. Journal of Health Care Compliance, 21(1), 17-26.

Hanratty, D., Kilicaslan, J., Wilding, H., \& Castle, D. (2019). A systematic review of efficacy of Collaborative Assessment and Management of Suicidality (CAMS) in managing suicide risk and deliberate self-harm in adult populations. Australasian Psychiatry : Bulletin of Royal Australian and New Zealand College of Psychiatrists, 27(6), 559-564. https://doi.org/10.1177/1039856219848832

Havelock, G. (1973). The change agent's guide to innovation in education. Educational Technology Publications.

Hinrichs, R. J., Bakker, C. J., Brigham, T. J., Ginier, E. C., Stevens, G. A., \& Alpi, K. M. (2020). Exploring interprofessional collaboration and attitudes of health sciences librarians. Journal of the Medical Library Association, 108(3), 440-451. https://doi.org/10.5195/jmla.2020.804

Hofstra, E., van Nieuwenhuizen, C., Bakker, M., Özgül, D., Elfeddali, I., de Jong, S. J., \& van der Feltz-Cornelis, C. M. (2020). Effectiveness of suicide prevention interventions: A systematic review and meta-analysis. General Hospital Psychiatry, 63, 127-140. https://doi.org/10.1016/j.genhosppsych.2019.04.011

Hogan, M. F., \& Goldstein Grumet, J. (2016). Suicide prevention: An emerging priority for health care. Health Affairs, 35(6), 1084-1090. https://doi.org/10.1377/hlthaff.2015.1672

Hussain, S. T., Lei, S., Akram, T., Haider, M. J., Hussain, S. H., \& Ali, M. (2018). Kurt Lewin's change model: A critical review of the role of leadership and employee involvement in 
organizational change. Journal of Innovation \& Knowledge, 3(3), 123-127.

https://doi.org/10.1016/j.jik.2016.07.002

Imran, J. B., Richmond, R. E., Madni, T. D., Roaten, K., Clark, A. T., Huang, E. Y., Mokdad, A.

A., Taveras, L. R., Abdelfattah, K. R., Cripps, M. W., \& Eastman, A. L. (2018).

Determining suicide risk in trauma patients using a universal screening program. The

Journal of Trauma and Acute Care Surgery, 85(1), 182-186.

https://doi.org/10.1097/TA.0000000000001899

Institute for Healthcare Improvement. (2020). What is a bundle? Improving health and healthcare worldwide.

https://www.ihi.org/resources/Pages/ImprovementStories/WhatIsaBundle.aspx

Interian, A., Chesin, M., Kline, A., Miller, R., St Hill, L., Latorre, M., Shcherbakov, A., King, A., \& Stanley, B. (2018). Use of the Columbia-Suicide Severity Rating Scale (C-SSRS) to classify suicidal behaviors. Archives of Suicide Research : Official Journal of the International Academy for Suicide Research, 22(2), 278-294.

https://doi.org/10.1080/13811118.2017.1334610

Jager, J., Putnick, D. L., \& Bornstein, M. H. (2017). II. More than just convenient: The Scientific merits of homogeneous convenience samples. Monographs of the Society for Research in Child Development, 82(2), 13-30. https://doi.org/10.1111/mono.12296

Jobes, D. (2012). The collaborative assessment and management of suicidality (CAMS): An evolving evidence-based clinical approach to suicidal risk. Suicide and Life-Threatening Behavior, 42(6), 640-653. https://doi.org/10.1111/j.1943-278x.2012.00119.x

Jobes, D., Gregorian, M., \& Colborn, V. (2018). A stepped care approach to clinical suicide prevention. Psychological Services, 15(3), 243-250. https://doi.org/10.1037/ser0000229 
Kang H. (2013). The prevention and handling of the missing data. Korean journal of anesthesiology, 64(5), 402-406. https://doi.org/10.4097/kjae.2013.64.5.402

Katz, I., Barry, C. N., Cooper, S. A., Kasprow, W. J., \& Hoff, R. A. (2020). Use of the Columbia-Suicide Severity Rating Scale (C-SSRS) in a large sample of Veterans receiving mental health services in the Veterans Health Administration. Suicide \& LifeThreatening Behavior, 50(1), 111-121. https://doi.org/10.1111/sltb.12584

King, C. A., Horwitz, A., Czyz, E., \& Lindsay, R. (2017). Suicide risk screening in healthcare settings: Identifying males and females at risk. Journal of clinical psychology in medical settings, 24(1), 8-20. https://doi.org/10.1007/s10880-017-9486-y

Kodama, Y., \& Fukahori, H. (2017). Nurse managers' attributes to promote change in their wards: A qualitative study. Nursing Open, 4(4), 209-217. https://doi.org/10.1002/nop2.87

Leedy, P., \& Ormrod, J. (2011). Practical research: Planning and design (10th Ed.). Pearson/Merrill Prentice Hall.

Lewin, K. (1947). Lewin's change management model. Understanding the three stages of change. http://www.mindtools.com/pages/article/newPPM 94.htm. (Retrieved on $06 / 01 / 2020)$

Little, V., Neufeld, J., \& Cole, A. R. (2018). Integrating safety plans for suicidal patients into patient portals: Challenges and opportunities. Psychiatric Services, 69(6), 618-619. https://doi.org/10.1176/appi.ps.201700458

Matarazzo, B. B., Brown, G. K., Stanley, B., Forster, J. E., Billera, M., Currier, G. W., et al. (2018). Predictive validity of the Columbia suicide severity rating scale among a cohort 
of at-risk veterans. Suicide and Life-Threatening Behavior, 49(5),1255-1265. https://doi.org/10.1111/sltb.12515

McCabe, R., Garside, R., Backhouse, A., \& Xanthopoulou, P. (2018). Effectiveness of brief psychological interventions for suicidal presentations: A systematic review. $B M C$ Psychiatry, 18(1), 120. https://doi.org/10.1186/s12888-018-1663-5

McBride, S. M., Braz, V. A., \& Jones, C. W. (2018). Occult suicidality and psychiatric disease among emergency department patients with low-acuity chief complaints. The Western Journal of Emergency Medicine, 19(3), 573-578. https://doi.org/10.5811/westjem.2018.2.36399

Meerwijk, E. L., Parekh, A., Oquendo, M. A., Allen, I. E., Franck, L. S., \& Lee, K. A. (2016). Direct versus indirect psychosocial and behavioural interventions to prevent suicide and suicide attempts: A systematic review and meta-analysis. The Lancet. Psychiatry, 3(6), 544-554. https://doi.org/10.1016/S2215-0366(16)00064-X

Moher D, Liberati A, Tetzlaff J, Altman DG (2009). The PRISMA Group. Preferred reporting items for systematic reviews and meta-analyses: The PRISMA Statement. PLoS Med 6(7), e1000097. doi:10.1371/journal.pmed 1000097

Morgan, S., Pullon, S., \& McKinlay, E. (2015). Observation of interprofessional collaborative practice in primary care teams: An integrative literature review. International Journal of Nursing Studies, 52 (2015), 1217-1230. doi:10.1016/j.ijnurstu.2015.03.008

Naghavi, M. (2019). Global, regional, and national burden of suicide mortality 1990 to 2016 : Systematic analysis for the Global Burden of Disease Study 2016. BMJ: British Medical Journal, 364 . 
National Institute of Mental Health. (2020). Suicide prevention.

https://www.nimh.nih.gov/topics/topic-page-suicide-prevention.shtml

O’Connor, L., Larkin, C., Ibrahim, A. F., Allen, M., Wang, B., \& Boudreaux, E. D. (2020).

Development and pilot study of simple suicide risk rulers for use in the emergency department. General Hospital Psychiatry, 63, 97-102.

https://doi.org/10.1016/j.genhosppsych.2018.08.004

Olawale F. Ayilara, Lisa Zhang, Tolulope T. Sajobi, Richard Sawatzky, Eric Bohm, \& Lisa M. Lix. (2019). Impact of missing data on bias and precision when estimating change in patient-reported outcomes from a clinical registry. Health and Quality of Life Outcomes, 17(1), 1-9. https://doi.org/10.1186/s12955-019-1181-2

Posner, K., Brown, G. K., Stanley, B., Brent, D. A., Yershova, K. V., Oquendo, M. A., Currier, G. W., Melvin, G. A., Greenhill, L., Shen, S., \& Mann, J. J. (2011). The ColumbiaSuicide Severity Rating Scale: Initial validity and internal consistency findings from three multisite studies with adolescents and adults. The American Journal of Psychiatry, 168(12), 1266-1277. https://doi.org/10.1176/appi.ajp.2011.10111704

Roaten, K., Johnson, C., Genzel, R., Khan, F., \& North, C. S. (2018). ). Development and implementation of a universal suicide risk screening program in a safety-net hospital system. The Joint Commission Journal on Quality and Patient Safety, 44(1), 4-11. https://doi.org/10.1016/j.jcjq.2017.07.006

Sadock, B.J., \& Sadock, V. A. (2014). Pocket handbook of clinical psychiatry (5th ed.). Lippincott 
Sarkar, J. (2013). Legal and ethical considerations in suicide prevention

http://psychscene.com/wp-content/uploads/2018/03/Legal-and-ethical-considerations-insuicide.pdf

Schot, E., Tummers, L., \& Noordegraaf, M. (2020). Working on working together. A systematic review on how healthcare professionals contribute to interprofessional collaboration.

Journal of Interprofessional Care, 34(3), 332-342.

https://doi.org/10.1080/13561820.2019.1636007

Schmutte, T., Olfson, M., Xie, M., \& Marcus, S. C. (2019). Deliberate self-harm in older adults: A national analysis of US emergency department visits and follow-up care. International Journal of Geriatric Psychiatry, 34(7), 1058-1069. https://doi.org/10.1002/gps.5109

Simon, M., \& Goes, J. (2011). Dissertation and scholarly research: Recipes for success. CreateSpace.

Snyder, D. J., Ballard, E. D., Stanley, I. H., Ludi, E., Kohn-Godbout, J., Pao, M., \& Horowitz, L. M. (2017). Patient opinions about screening for suicide risk in the adult medical inpatient unit. The Journal of Behavioral Health Services \& Research, 44(3), 364-372. https://doi.org/10.1007/s11414-016-9498-7

Stanley, B., \& Brown, G. K. (2012). Safety planning intervention: A brief intervention to mitigate suicide risk. Cognitive and Behavioral Practice, 19(2), 256-264. https://doi.org/10.1016/j.cbpra.2011.01.001

Sylvia, M. L. \& Terhaar, M. F. (2018). Clinical analytics and data management of the DNP ( $2^{\text {nd }}$ ed.). Springer.

Taylor, M. J., McNicholas, C., Nicolay, C., Darzi, A., Bell, D., \& Reed, J. E. (2014). Systematic 
review of the application of the plan-do-study-act method to improve quality in healthcare. BMJ Quality \& Safety, 23, 290-298. doi:10.1136/bmjqs-2013-001862

The Columbia Lighthouse Project. (2016). About the protocol. https://cssrs.columbia.edu/thecolumbia-scale-c-ssrs/about-the-scale/

The State of the State. (n,d). Texas facts. file://C:/Users/cynthia.akindele/Downloads/Texas\%20facts-\%20Suicide.pdf The University of Texas System (2017). Suicide in Texas. https://www.utsystem.edu/sites/default/files/news/assets/Suicide\%20in\%20Texas.pdf

Tracy, J. A. (2020). Be a champion for change by using Lewin's 3 -stage Model of Change. $R D H$, $40(2), 18-20$.

Vasconcelos Neto, P. J. A., Moreira, R. D. S., Oliveira Júnior, F. J. M., \& Ludermir, A. B. (2020). Suicide attempt, post-traumatic stress disorder and associated factors in women of Recife. Revista Brasileira de Epidemiologia, 23, e200010. http://dx .doi.org/10.1590/1980-549720200010

World Health Organization. (2020). Quality of suicide mortality data. http://www.who.int/mental_health/suicide-prevention/mortality_data_quality/en/ World Health Organization [WHO]. (2020). Suicide data. https://www.who.int/mental_health/prevention/suicide/suicideprevent/en/ Zero Suicide Toolkit. (2020). Zero suicide. http://zerosuicide.edc.org/toolkit 
Table 1

Participant Demographics $(n=32)$

\begin{tabular}{lll}
\hline \multicolumn{3}{c}{ Summary Statistics } \\
\cline { 1 - 2 }$\underline{\text { Age (in years) }}$ & $\underline{n}$ & $\underline{\%}$ \\
18 to 25 & 5 & 15.6 \\
26 to 35 & 6 & 18.75 \\
36 to 45 & 3 & 9.4 \\
46 to 55 & 3 & 9.4 \\
56 to 66 & 5 & 15.6 \\
Over 66 & 10 & 31.25 \\
Gender & & \\
Male & 17 & 53.1 \\
Female & 15 & 46.9 \\
\hline
\end{tabular}

Table 2

Pre and Post Intervention Statistics $(n=32)$

\begin{tabular}{lcccc}
\hline & \multicolumn{2}{l}{ Pre-Intervention } & \multicolumn{2}{l}{ Post-Intervention } \\
& $\underline{M}$ & $\underline{S D}$ & $\underline{M}$ & $\underline{S D}$ \\
C-SSRS & .81 & .30 & .75 & .18 \\
\hline
\end{tabular}

Note. $M=$ mean, $S D=$ standard deviation

\section{Table 3}

Independent Samples t-Test Results

\section{Statistics}

\begin{tabular}{|c|c|c|c|}
\hline & $\underline{t \text {-test value }}$ & $\underline{d f}$ & $p$-value \\
\hline C-SSRS & 1.87 & 31 & $.07^{+}$ \\
\hline
\end{tabular}


Table 4

Budget

\begin{tabular}{|c|c|c|c|}
\hline EXPENSES & & REVENUE & \\
\hline Direct & $\$ 120$ & Billing & $\$ 0$ \\
\hline Salary and benefits & $\$ 0$ & Grants & $\$ 0$ \\
\hline Supplies & $\$ 220$ & Institutional budget support & $\$ 0$ \\
\hline Services & $\$ 50$ & & \\
\hline Statistician & $\$ 800$ & & \\
\hline $\begin{array}{l}\text { Supplies and materials } \\
\text { Stationery }\end{array}$ & $\$ 50$ & & \\
\hline Transportation & $\$ 100$ & & \\
\hline Indirect & 0 & & \\
\hline Overhead & 0 & & \\
\hline Total Expenses & $\$ 1,340$ & Total Revenue & $\$ 0$ \\
\hline Net Balance $\$ 1,340$ & & & \\
\hline
\end{tabular}




\section{Figure 1}

PRISMA 2020 Flow Diagram

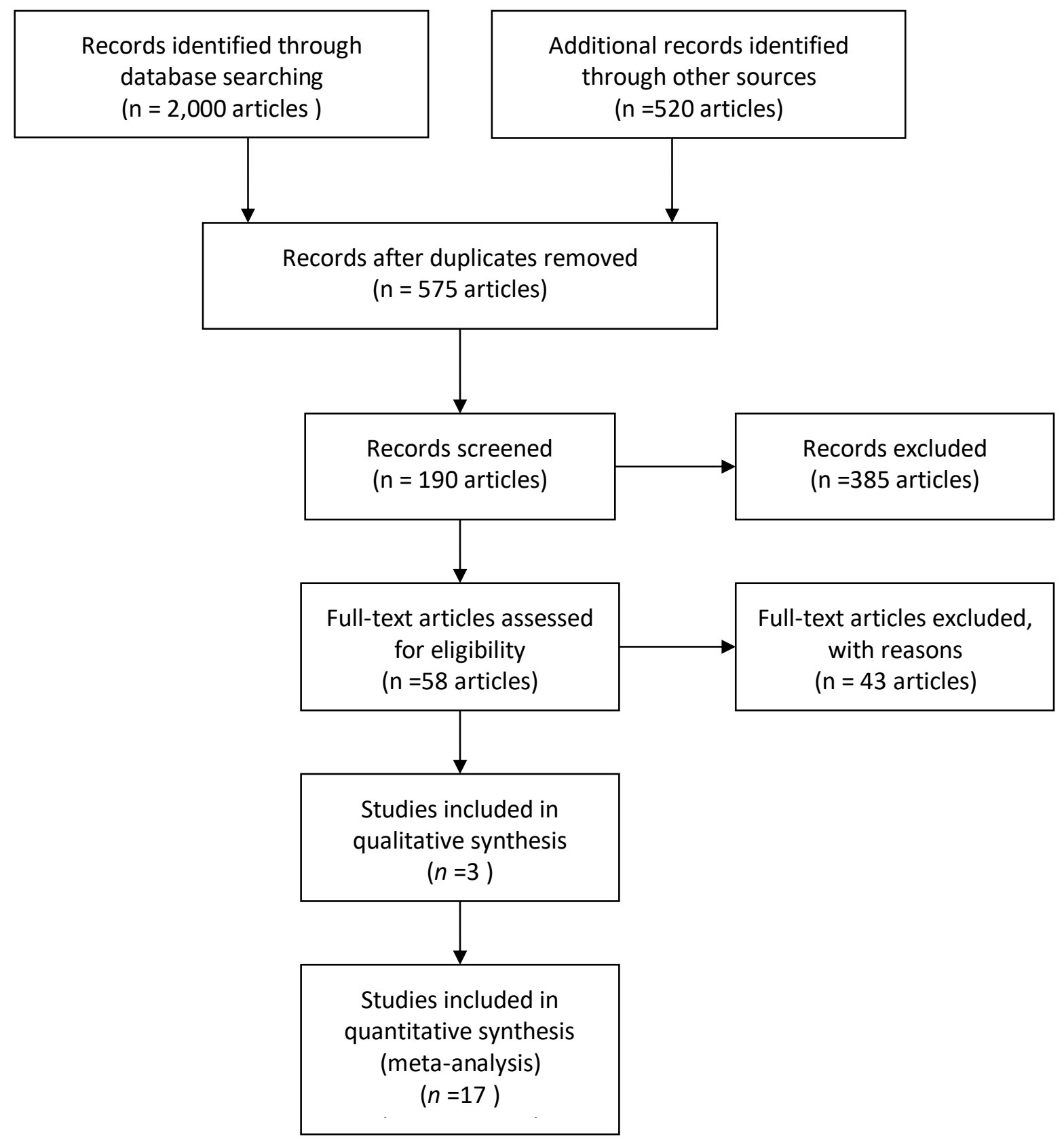




\section{Appendix A}

\section{Summary of Primary Research Evidence}

\begin{tabular}{|c|c|c|c|c|c|c|}
\hline Citation & $\begin{array}{l}\text { Design, Level } \\
\text { Quality Grade }\end{array}$ & $\begin{array}{c}\text { Sample } \\
\text { Sample size }\end{array}$ & $\begin{array}{l}\text { Intervention } \\
\text { Comparison }\end{array}$ & $\begin{array}{l}\text { Theoretical } \\
\text { Foundation }\end{array}$ & Outcome Definition & $\begin{array}{l}\text { Usefulness } \\
\text { Results } \\
\text { Key Findings }\end{array}$ \\
\hline $\begin{array}{l}\text { McCabe, } \\
\text { et al., } \\
2018 .\end{array}$ & $\begin{array}{l}\text { Design: } \\
\text { Randomized } \\
\text { Controlled } \\
\text { Studies. } \\
\text { Quality: Good. } \\
\text { Grade: A } \\
\text { Level :1 }\end{array}$ & $\begin{array}{l}3412 \text { participants were } \\
\text { used. Both Cochrane } \\
\text { Risk of Bias, and } \\
\text { CASP Tools for } \\
\text { Randomized } \\
\text { Controlled Trials were } \\
\text { used independently. } \\
\text { The method reflects } \\
\text { the diversity of } \\
\text { included studies. } \\
\text { Before the data } \\
\text { extraction was } \\
\text { finalized, there were } \\
\text { checks and balances } \\
\text { by the three authors } \\
\text { involved in the } \\
\text { studies. }\end{array}$ & $\begin{array}{l}\text { Having compared all } \\
\text { the interventions in the } \\
\text { study, it is evident that } \\
\text { brief psychological } \\
\text { interventions appears } \\
\text { to be effective in } \\
\text { reducing suicide and } \\
\text { suicide attempts. }\end{array}$ & $\begin{array}{l}\text { Health } \\
\text { Literate Care } \\
\text { Model }\end{array}$ & $\begin{array}{l}\text { Although the } \\
\text { evidence base is } \\
\text { small, brief } \\
\text { psychological } \\
\text { interventions appear } \\
\text { to be effective in } \\
\text { reducing suicide and } \\
\text { suicide attempts. }\end{array}$ & $\begin{array}{l}\text { It was discovered that } \\
\text { two trials that measured } \\
\text { suicidal ideation found } \\
\text { no impact. Two studies } \\
\text { showed fewer suicide } \\
\text { attempts, one showed } \\
\text { fewer suicides and one } \\
\text { found an effect on } \\
\text { depression. } \\
\text { Usefulness: The } \\
\text { interventions could } \\
\text { potentially be adopted } \\
\text { for inpatient and other } \\
\text { outpatient settings. } \\
\text { Early engagement and } \\
\text { therapeutic intervention } \\
\text { based on psychological } \\
\text { theories of suicidal } \\
\text { behavior, sustained in } \\
\text { follow-up contacts, } \\
\text { may be particularly } \\
\text { beneficial. }\end{array}$ \\
\hline $\begin{array}{l}\text { Roaten, et } \\
\text { al., } 2018 .\end{array}$ & $\begin{array}{l}\text { Design: Quasi- } \\
\text { experiment } \\
\text { Quality: Good } \\
\text { Grade: Good }\end{array}$ & $\begin{array}{l}\text { Prevalence data on } \\
\text { suicide risk levels are } \\
\text { provided for } 328,064 \\
\text { adult encounters from }\end{array}$ & $\begin{array}{l}\text { This program has } \\
\text { brought a paradigm } \\
\text { shift from the previous } \\
\text { state, in which very }\end{array}$ & $\begin{array}{l}\text { None clearly } \\
\text { stated }\end{array}$ & $\begin{array}{l}\text { An evidence-based } \\
\text { practice change } \\
\text { project involving a } \\
\text { universal suicide }\end{array}$ & $\begin{array}{l}\text { Approximately half of } \\
\text { the screens were } \\
\text { completed in the } \\
\text { outpatient clinics, more }\end{array}$ \\
\hline
\end{tabular}




\begin{tabular}{|c|c|c|c|c|c|c|}
\hline Citation & $\begin{array}{c}\text { Design, Level } \\
\text { Quality Grade }\end{array}$ & $\begin{array}{c}\text { Sample } \\
\text { Sample size }\end{array}$ & $\begin{array}{l}\text { Intervention } \\
\text { Comparison }\end{array}$ & $\begin{array}{l}\text { Theoretical } \\
\text { Foundation }\end{array}$ & Outcome Definition & $\begin{array}{l}\text { Usefulness } \\
\text { Results } \\
\text { Key Findings }\end{array}$ \\
\hline & Level III & $\begin{array}{l}\text { the first six months of } \\
\text { the screening } \\
\text { program. Therefore, } \\
\text { the sample size }(\mathrm{N}) \text { is } \\
328,064 \text {. }\end{array}$ & $\begin{array}{l}\text { few patients served by } \\
\text { the system were ever } \\
\text { asked about or } \\
\text { discussed suicide with } \\
\text { providers during health } \\
\text { care encounters, to a } \\
\text { model in which all } \\
\text { patients are } \\
\text { systematically screened } \\
\text { for suicide risk. }\end{array}$ & & $\begin{array}{l}\text { screening program } \\
\text { was designed and } \\
\text { developed in a large } \\
\text { safety-net health care } \\
\text { system. }\end{array}$ & $\begin{array}{l}\text { than } 40 \% \text { in the } \\
\text { emergency department } \\
\text { (ED), and slightly less } \\
\text { than } 5 \% \text { in the hospital } \\
\text { inpatient units. In the } \\
\text { ED, } 6.3 \% \text { of the } \\
\text { screens were positive, } \\
\text { as were } 1.6 \% \text { in the } \\
\text { inpatient units, and } \\
2.1 \% \text { in the outpatient } \\
\text { clinics. The odds of a } \\
\text { positive suicide } \\
\text { screening in the ED } \\
\text { was } 4.29 \text { times higher } \\
\text { than the inpatient units } \\
\text { and } 3.13 \text { times higher } \\
\text { than the outpatient } \\
\text { clinics. }\end{array}$ \\
\hline $\begin{array}{l}\text { McBride, } \\
\text { et.al., } \\
2018 .\end{array}$ & $\begin{array}{l}\text { Design: } \\
\text { Prospective } \\
\text { cross-sectional } \\
\text { survey. } \\
\text { Quality: Good } \\
\text { Level IV }\end{array}$ & $\begin{array}{l}\text { The sample size is } 816 \\
\text { participants. } \\
\text { Participants completed } \\
\text { two previously } \\
\text { validated mental } \\
\text { health screening } \\
\text { instruments, the } \\
\text { Patient Health } \\
\text { Questionnaire }\end{array}$ & $\begin{array}{l}\text { None Stated } \\
\text { Interian Interian et al., } \\
2018\end{array}$ & $\begin{array}{l}\text { Knowledge- } \\
\text { to-Action } \\
\text { (KTA) } \\
\text { Process }\end{array}$ & $\begin{array}{l}\text { Patients presenting to } \\
\text { emergency } \\
\text { departments (ED) are } \\
\text { often screened for } \\
\text { suicidality, even when } \\
\text { their chief complaint } \\
\text { does not involve } \\
\text { mental health } \\
\text { concerns. Patient } \\
\text { receptiveness to ED- }\end{array}$ & $\begin{array}{l}\text { It was found out that of } \\
816 \text { participants, } 11 \% \\
\text { were at high risk for } \\
\text { suicide. Many were } \\
\text { receptive to addressing } \\
\text { mental health issues } \\
\text { during the ED visit. } \\
\text { Usefulness:that } \\
\text { screening low acuity }\end{array}$ \\
\hline
\end{tabular}




\begin{tabular}{|c|c|c|c|c|c|c|}
\hline Citation & $\begin{array}{l}\text { Design, Level } \\
\text { Quality Grade }\end{array}$ & $\begin{array}{c}\text { Sample } \\
\text { Sample size }\end{array}$ & $\begin{array}{l}\text { Intervention } \\
\text { Comparison }\end{array}$ & $\begin{array}{l}\text { Theoretical } \\
\text { Foundation }\end{array}$ & Outcome Definition & $\begin{array}{l}\text { Usefulness } \\
\text { Results } \\
\text { Key Findings }\end{array}$ \\
\hline & & $\begin{array}{l}\text { for Depression and } \\
\text { Anxiety and the } \\
\text { Suicide Behaviors } \\
\text { Questionnaire-- } \\
\text { Revised. }\end{array}$ & & & $\begin{array}{l}\text { based mental health } \\
\text { screening and } \\
\text { intervention is } \\
\text { unknown, particularly } \\
\text { among patients with } \\
\text { low-acuity. }\end{array}$ & $\begin{array}{l}\text { ED patients for mental } \\
\text { health concerns may be } \\
\text { useful, though studies } \\
\text { assessing the impact of } \\
\text { screening on patient- } \\
\text { oriented outcomes are } \\
\text { needed. }\end{array}$ \\
\hline $\begin{array}{l}\text { Interian et } \\
\text { al., } 2018 .\end{array}$ & $\begin{array}{l}\text { Design: } \\
\text { Randomized } \\
\text { Controlled } \\
\text { Studies. } \\
\text { Quality: Good. } \\
\text { Grade: A } \\
\text { Level :1 }\end{array}$ & (1) & $\begin{array}{l}\text { Two scenarios were } \\
\text { compared actual } \\
\text { attempt and interrupted } \\
\text { attempt. Like the } \\
\text { previous two cases, this } \\
\text { case involved two } \\
\text { separate self- injurious } \\
\text { behaviors. Both of } \\
\text { them were } \\
\text { characterized by } \\
\text { suicidal intent. }\end{array}$ & $\begin{array}{l}\text { Hildegard } \\
\text { Peplau's } \\
\text { theory of } \\
\text { interpersonal } \\
\text { relations }\end{array}$ & $\begin{array}{l}\text { The cases showed } \\
\text { some of the } \\
\text { difficulties that have } \\
\text { been part of the } \\
\text { debate concerning a } \\
\text { classification system } \\
\text { for suicidal behaviors. }\end{array}$ & $\begin{array}{l}\text { A total of } 387 \text { C-SSRS } \\
\text { interviews had been } \\
\text { conducted and } 36 \text { cases } \\
\text { had been discussed and } \\
\text { tracked by study group. } \\
\text { Out of the } 113 \\
\text { interviews conducted at } \\
\text { baseline, an attempt } \\
\text { (actual, aborted, or } \\
\text { interrupted) or } \\
\text { preparatory behavior } \\
\text { was reported in } 105 \\
\text { (92.9\%) interviews. } \\
\text { Self-report of suicidal } \\
\text { intent can be highly } \\
\text { complicated by } \\
\text { ambivalence of intent, } \\
\text { and circumstances of } \\
\text { the evaluation }\end{array}$ \\
\hline $\begin{array}{l}\text { Snyder et } \\
\text { al., } 2017 .\end{array}$ & $\begin{array}{l}\text { Design: } \\
\text { Prospective } \\
\text { cross-sectional } \\
\text { survey. }\end{array}$ & $\begin{array}{l}\text { A convenience sample } \\
\text { of } 56 \text { adult } \\
\text { medical/surgical } \\
\text { patients, age } 18 \text { years }\end{array}$ & $\begin{array}{l}\text { The intervention } \\
\text { included } \\
\text { in-service trainings } \\
\text { with nurses, social }\end{array}$ & $\begin{array}{l}\text { None clearly } \\
\text { stated }\end{array}$ & $\begin{array}{l}81 \% \text { of patients } \\
\text { reported that they } \\
\text { believed all } \\
\text { medical/surgical }\end{array}$ & $\begin{array}{l}\text { It was concluded that } \\
\text { patients should be } \\
\text { asked directly about } \\
\text { suicide. Mental health } \\
\text { should also be an }\end{array}$ \\
\hline
\end{tabular}




\begin{tabular}{|c|c|c|c|c|c|c|}
\hline Citation & $\begin{array}{c}\text { Design, Level } \\
\text { Quality Grade }\end{array}$ & $\begin{array}{c}\text { Sample } \\
\text { Sample size }\end{array}$ & $\begin{array}{l}\text { Intervention } \\
\text { Comparison }\end{array}$ & $\begin{array}{l}\text { Theoretical } \\
\text { Foundation }\end{array}$ & Outcome Definition & $\begin{array}{l}\text { Usefulness } \\
\text { Results } \\
\text { Key Findings }\end{array}$ \\
\hline $\begin{array}{l}\text { Boudreaux } \\
\text { et al., } 2016\end{array}$ & $\begin{array}{l}\text { Design:time } \\
\text { series design } \\
\text { Quality: Good } \\
\text { Level I }\end{array}$ & $\begin{array}{l}\text { or older, who were } \\
\text { admitted to one of } \\
\text { three select inpatient } \\
\text { units at the National } \\
\text { Institutes of Health } \\
\text { (NIH) Clinical } \\
\text { Research Center } \\
\text { (CRC) were included. }\end{array}$ & $\begin{array}{l}\text { Research has } \\
\text { repeatedly suggested } \\
\text { that ED patients have } \\
\text { significant undetected } \\
\text { suicide risk. This the } \\
\text { first study to address } \\
\text { the key question of } \\
\text { whether detection } \\
\text { feasibly can be } \\
\text { increased by } \\
\text { implementing } \\
\text { universal suicide risk } \\
\text { screening protocols in } \\
\text { the ED. }\end{array}$ & $\begin{array}{l}\text { None clearly } \\
\text { stated }\end{array}$ & $\begin{array}{l}\text { The first outcome, } \\
\text { documentation of } \\
\text { intentional self-harm } \\
\text { ideation or behavior } \\
\text { screening, was } \\
\text { defined broadly as } \\
\text { any documentation of } \\
\text { past or current } \\
\text { intentional self-harm } \\
\text { ideation or behavior } \\
\text { appearing in the } \\
\text { record as either } \\
\text { present or absent. The } \\
\text { second outcome, } \\
\text { inten- } \\
\text { tional self-harm risk } \\
\text { detection, was defined } \\
\text { as past or current } \\
\text { intentional self-harm } \\
\text { ideation or behavior }\end{array}$ & $\begin{array}{l}\text { integral component in } \\
\text { the delivery of medical } \\
\text { care for patients.Also, } \\
\text { every provider should } \\
\text { be educated on the } \\
\text { importance of } \\
\text { intervening, protecting, } \\
\text { and keeping patients } \\
\text { safe in a hospital } \\
\text { setting. } \\
\text { Across the three phases } \\
\text { (N1/4236,791 ED visit } \\
\text { records), documented } \\
\text { screenings rose from } \\
26 \% \text { (Phase } 1 \text { ) to } 84 \% \\
\text { (Phase } 3 \text { ). Detection } \\
\text { rose from } 2.9 \% \text { to } \\
5.7 \% \text {. The majority of } \\
\text { detected intentional } \\
\text { self-harm was } \\
\text { confirmed as recent } \\
\text { suicidal ideation or } \\
\text { behavior by patient } \\
\text { interview. } \\
\text { Usefulness: If these } \\
\text { findings remain true } \\
\text { when scaled, the public } \\
\text { health impact could be } \\
\text { tremendous, because } \\
\text { identification of risk is }\end{array}$ \\
\hline
\end{tabular}




\begin{tabular}{|c|c|c|c|c|c|c|}
\hline Citation & $\begin{array}{c}\text { Design, Level } \\
\text { Quality Grade }\end{array}$ & $\begin{array}{c}\text { Sample } \\
\text { Sample size }\end{array}$ & $\begin{array}{l}\text { Intervention } \\
\text { Comparison }\end{array}$ & $\begin{array}{l}\text { Theoretical } \\
\text { Foundation }\end{array}$ & Outcome Definition & $\begin{array}{l}\text { Usefulness } \\
\text { Results } \\
\text { Key Findings }\end{array}$ \\
\hline & & & & & $\begin{array}{l}\text { documented as } \\
\text { positive in the ED } \\
\text { medical record. }\end{array}$ & $\begin{array}{l}\text { the first and necessary } \\
\text { step for preventing } \\
\text { suicide. }\end{array}$ \\
\hline $\begin{array}{l}\text { Katz, et } \\
\text { al., (2020) }\end{array}$ & $\begin{array}{l}\text { Design: Cohort } \\
\text { Studies } \\
\text { Quality: Good } \\
\text { Level IV }\end{array}$ & $\begin{array}{l}\text { Sample size: } 15,373 \\
\text { Veterans receiving } \\
\text { mental health services } \\
\text { at the VHA }\end{array}$ & $\begin{array}{l}\text { The intervention } \\
\text { explains that clinical } \\
\text { and administrative data } \\
\text { on documented suicide } \\
\text { attempts were obtained } \\
\text { from two sources and } \\
\text { data on self-reports of } \\
\text { suicidal ideation and } \\
\text { behaviors were from } \\
\text { responses to the C- } \\
\text { SSRS. }\end{array}$ & $\begin{array}{l}\text { The Health } \\
\text { Belief Model }\end{array}$ & $\begin{array}{l}\text { Analyses also showed } \\
\text { that scores based on } \\
\text { C-SSRS responses for } \\
\text { the past } 3 \text { months } \\
\text { were predictive of } \\
\text { suicide behavior. }\end{array}$ & $\begin{array}{l}\text { The result shows that } \\
\text { the tests of concurrent } \\
\text { validity found valid } \\
\text { relationship between } \\
\text { self-reports and } \\
\text { attempts reported in } \\
\text { VHA records, but there } \\
\text { were huge numbers of } \\
\text { clashing responses. In } \\
\text { tests of predictive } \\
\text { validity, area under the } \\
\text { ROC curve for } \\
\text { predicting future } \\
\text { attempts was }>0.8 \text {. It } \\
\text { was also noted that the } \\
\text { findings support the } \\
\text { value of screening and } \\
\text { the validity of the self } \\
\text { reports based on the C- } \\
\text { SSRS. }\end{array}$ \\
\hline $\begin{array}{l}\text { Hoftra et } \\
\text { al., } 2020\end{array}$ & $\begin{array}{l}\text { Design: Metal } \\
\text { analysis. } \\
\text { Quality: Good } \\
\text { Grade: B } \\
\text { Level: } 1\end{array}$ & $\begin{array}{l}\text { The meta-analysis was } \\
\text { performed in } 15 \\
\text { studies with } 29,071 \\
\text { participants. The } \\
\text { extraction of data was } \\
\text { performed } \\
\text { independently by two }\end{array}$ & $\begin{array}{l}\text { The interventions } \\
\text { comparison shows that } \\
\text { suicide prevention } \\
\text { interventions are } \\
\text { effective in preventing } \\
\text { both completed and } \\
\text { attempted suicides. The } \\
\text { effect size for }\end{array}$ & $\begin{array}{l}\text { Ida Jean } \\
\text { Orlando’s } \\
\text { (Pelletier's) } \\
\text { Nursing } \\
\text { Process } \\
\text { Theory }\end{array}$ & $\begin{array}{l}\text { Outcomes were } \\
\text { completed or } \\
\text { attempted suicides in } \\
\text { quantitative } \\
\text { measures, as defined } \\
\text { by healthcare } \\
\text { professionals (hospital } \\
\text { records, }\end{array}$ & $\begin{array}{l}\text { A significant effect was } \\
\text { found for suicide } \\
\text { prevention } \\
\text { interventions on } \\
\text { completed suicides and } \\
\text { on suicide attempts. } \\
\text { Regarding the } \\
\text { synergistic effect of }\end{array}$ \\
\hline
\end{tabular}




\begin{tabular}{|c|c|c|c|c|c|c|}
\hline Citation & $\begin{array}{l}\text { Design, Level } \\
\text { Quality Grade }\end{array}$ & $\begin{array}{c}\text { Sample } \\
\text { Sample size }\end{array}$ & $\begin{array}{l}\text { Intervention } \\
\text { Comparison }\end{array}$ & $\begin{array}{l}\text { Theoretical } \\
\text { Foundation }\end{array}$ & Outcome Definition & $\begin{array}{l}\text { Usefulness } \\
\text { Results } \\
\text { Key Findings }\end{array}$ \\
\hline & & $\begin{array}{l}\text { researchers (EH and } \\
\text { DÖ). In } \\
\text { the case of non- } \\
\text { consensus, a third } \\
\text { assessor (CFC) was } \\
\text { consulted to make the } \\
\text { final decision. }\end{array}$ & $\begin{array}{l}\text { completed suicides is } \\
\text { larger than for } \\
\text { attempted suicides. }\end{array}$ & & $\begin{array}{l}\text { questionnaires, or } \\
\text { interview) or } \\
\text { coroners' records. }\end{array}$ & $\begin{array}{l}\text { multilevel } \\
\text { interventions, meta- } \\
\text { regression showed a } \\
\text { significantly higher } \\
\text { effect related to the } \\
\text { number of levels of the } \\
\text { intervention. } \\
\text { Usefulness: Suicide } \\
\text { prevention } \\
\text { interventions are } \\
\text { effective in preventing } \\
\text { completed and } \\
\text { attempted suicides and } \\
\text { should be widely } \\
\text { implemented. }\end{array}$ \\
\hline $\begin{array}{l}\text { Matarazzo } \\
\text { et al., } \\
2018 \text {. }\end{array}$ & $\begin{array}{l}\text { Design: Quasi- } \\
\text { experimental } \\
\text { Studies. } \\
\text { Quality: Good. } \\
\text { Grade: A } \\
\text { Level :2 }\end{array}$ & $\begin{array}{l}\text { Sample size }=237 \text { out } \\
\text { of } 332 \text { enrolled } \\
\text { participants. } \\
\text { The majority of } \\
\text { participants were male } \\
(88 \%) \text {, white }(57 \%) \text {, } \\
\text { and had a mental } \\
\text { health diagnosis at } \\
\text { baseline }(81 \%) \text { with a } \\
\text { mean age of } 46.1 \\
(\mathrm{SD}=13.9)\end{array}$ & $\begin{array}{l}\text { Of the sample of } 237, \\
142 \text { participants } \\
\text { received the } \\
\text { intervention and } 95 \\
\text { participants were from } \\
\text { control sites where } \\
\text { usual clinical care was } \\
\text { enhanced by additional } \\
\text { research contacts. }\end{array}$ & $\begin{array}{l}\text { Iowa Model } \\
\text { of Evidence } \\
\text { Based- } \\
\text { Practice } \\
\text { Model }\end{array}$ & $\begin{array}{l}\text { Baseline C-SSRS } \\
\text { intensity subscale } \\
\text { scores significantly } \\
\text { predicted actual } \\
\text { attempts, interrupted } \\
\text { attempts, and any } \\
\text { behavior for } \\
\text { allavailable data. }\end{array}$ & $\begin{array}{l}\text { It was concluded that } \\
\text { the C-SSRS is a } \\
\text { psychometrically sound } \\
\text { measure which can be } \\
\text { used to augment } \\
\text { suicide risk assessment } \\
\text { with veterans at risk for } \\
\text { suicide. } \\
\text { It was also noted that } \\
\text { comprehensive suicide } \\
\text { risk assessment via } \\
\text { clinical interview } \\
\text { should be conducted, } \\
\text { and an individualized } \\
\text { safety planning should } \\
\text { be developed to help }\end{array}$ \\
\hline
\end{tabular}




\begin{tabular}{|c|c|c|c|c|c|c|}
\hline Citation & $\begin{array}{l}\text { Design, Level } \\
\text { Quality Grade }\end{array}$ & $\begin{array}{c}\text { Sample } \\
\text { Sample size }\end{array}$ & $\begin{array}{l}\text { Intervention } \\
\text { Comparison }\end{array}$ & $\begin{array}{l}\text { Theoretical } \\
\text { Foundation }\end{array}$ & Outcome Definition & $\begin{array}{l}\text { Usefulness } \\
\text { Results } \\
\text { Key Findings }\end{array}$ \\
\hline & & & & & & $\begin{array}{l}\text { mitigate risk among } \\
\text { these individuals. }\end{array}$ \\
\hline $\begin{array}{l}\text { Schmutte, } \\
\text { et al., } \\
(2020) \text {. }\end{array}$ & $\begin{array}{l}\text { Design: } \\
\text { Quantitative } \\
\text { Cross Sectional } \\
\text { survey design } \\
\text { along with a } \\
\text { retrospective } \\
\text { chart review } \\
\text { Level: III } \\
\text { Quality: Good } \\
\text { Grade: C } \\
\text { Moderate }\end{array}$ & $\begin{array}{l}\text { The sanple size is } \\
52,383 \text {. The cohort } \\
\text { was extracted from } \\
2015 \text { national claims } \\
\text { from the Medicare } \\
\text { Provider Analysis and } \\
\text { Review (MedPAR), } \\
\text { outpatient, and carrier } \\
\text { files. The cohort was } \\
\text { restricted to adults } \\
\text { aged 65+ years with } \\
\text { ED visits for suicide } \\
\text { attempt, suicidal } \\
\text { ideation, or deliberate } \\
\text { self-harm. }\end{array}$ & $\begin{array}{l}\text { Emergency department } \\
\text { visits for self-harm and } \\
\text { suicidal ideation } \\
\text { have increased for US } \\
\text { older adults. } \\
\text { Consequently, there is } \\
\text { a need to investigate } \\
\text { the discharge } \\
\text { disposition, clinical } \\
\text { recognition of mental } \\
\text { disorder, and 30-day } \\
\text { follow-up mental } \\
\text { health outpatient care } \\
\text { of older adults treated } \\
\text { in emergency } \\
\text { departments for suicide } \\
\text { attempt (SA), suicidal } \\
\text { ideation (SI), or } \\
\text { deliberate self-harm } \\
\text { (DSH). }\end{array}$ & $\begin{array}{l}\text { Health } \\
\text { Literate Care } \\
\text { Model }\end{array}$ & $\begin{array}{l}\text { The three outcome } \\
\text { variables were: 1) } \\
\text { discharge dis- } \\
\text { position (percentage } \\
\text { discharged to } \\
\text { community), 2) } \\
\text { diagnosis of mental } \\
\text { disorder during the } \\
\text { ED visit (percentage } \\
\text { with mental disorder } \\
\text { discharged from ED), } \\
\text { and 3) follow-up } \\
\text { outpatient mental } \\
\text { healthcare within } 30 \\
\text { days of ED discharge } \\
\text { back to the } \\
\text { community. }\end{array}$ & $\begin{array}{l}\text { Encounters for SA and } \\
\text { SI were less likely than } \\
\text { those for DSH to be } \\
\text { dis-charged to the } \\
\text { community. Among } \\
\text { community discharges, } \\
\text { SA and SI encounters } \\
\text { were more likely than } \\
\text { DSH encounters to be } \\
\text { diagnosed with a } \\
\text { mental disorder in the } \\
\text { emergency department. } \\
\text { Encounters for SA and } \\
\text { SI were also more } \\
\text { likely than DSH } \\
\text { encounters to receive } \\
\text { follow-up mental care. }\end{array}$ \\
\hline
\end{tabular}




\section{Appendix B}

\section{Summary of Systematic Reviews (SR)}

\begin{tabular}{|c|c|c|c|c|c|c|c|}
\hline Citation & $\begin{array}{l}\text { Quality } \\
\text { Grade }\end{array}$ & Question & Search Strategy & $\begin{array}{l}\text { Inclusion/ } \\
\text { Exclusion } \\
\text { Criteria }\end{array}$ & $\begin{array}{l}\text { Data Extraction and } \\
\text { Analysis }\end{array}$ & Key Findings & $\begin{array}{l}\text { Usefulness/Recommendation/ } \\
\text { Implications }\end{array}$ \\
\hline $\begin{array}{l}\text { McCabe, } \\
\text { Garside, } \\
\text { Backhouse \& } \\
\text { Xanthopoulou, } \\
\text { 2018). }\end{array}$ & $\begin{array}{l}\text { Grade A } \\
\text { (High) }\end{array}$ & $\begin{array}{l}\text { What is the } \\
\text { impact of } \\
\text { suicidal } \\
\text { ideation on } \\
\text { emergency } \\
\text { department } \\
\text { patients? }\end{array}$ & $\begin{array}{l}\text { MEDLINE in Process } \\
\text { (Ovid), PsycINFO } \\
\text { (Ovid), EMBASE } \\
\text { (Ovid), The Cochrane } \\
\text { Central Register of } \\
\text { Controlled Trials } \\
\text { (CENTRAL) (Wiley } \\
\text { Online Library) and } \\
\text { CINHAL (EBSCO). }\end{array}$ & $\begin{array}{l}\text { Inclusions } \\
\text { Participants of } \\
\text { any age and } \\
\text { gender at risk of } \\
\text { suicide. } \\
\text { Exclusions: } \\
\text { Assisted suicide; } \\
\text { Self-harm without } \\
\text { intent to die, i.e., } \\
\text { direct, deliberate } \\
\text { destruction of } \\
\text { one' s own body } \\
\text { tissue in the } \\
\text { absence of intent } \\
\text { to die, which } \\
\text { differs from } \\
\text { suicide attempts } \\
\text { with respect to } \\
\text { intent, lethality, } \\
\text { chronicity, } \\
\text { methods, } \\
\text { cognitions, } \\
\text { reactions, } \\
\text { aftermath, } \\
\text { demographics and } \\
\text { prevalence }\end{array}$ & $\begin{array}{l}\text { Data extraction was } \\
\text { formed based on the } \\
\text { Cochrane Risk of Bias } \\
\text { Tool for Randomized } \\
\text { Controlled Trials, } \\
\text { which we modified to } \\
\text { reflect the diversity of } \\
\text { included studies. The } \\
\text { extraction form was } \\
\text { piloted (RM, AB, PX) } \\
\text { before being finalised. } \\
\text { Data was extracted by } \\
\text { one author (RM/PX) } \\
\text { and checked by } \\
\text { another (RM, AB, } \\
\text { PX).The analyses } \\
\text { involved developing a } \\
\text { preliminary synthesis, } \\
\text { focusing on } \\
\text { the outcomes, } \\
\text { interventions and } \\
\text { heterogeneity across } \\
\text { the studies, followed } \\
\text { by iteratively } \\
\text { exploring } \\
\text { relationships in } \\
\text { the data, contexts of } \\
\text { the interventions and } \\
\text { mechanisms } \\
\text { for change, using } \\
\text { visual representations } \\
\text { (tables). }\end{array}$ & $\begin{array}{l}\text { Two trials that } \\
\text { measured suicidal } \\
\text { ideation found no } \\
\text { impact. Two } \\
\text { studies showed } \\
\text { fewer suicide } \\
\text { attempts, one } \\
\text { showed fewer } \\
\text { suicides and one } \\
\text { found an effect on } \\
\text { depression. }\end{array}$ & $\begin{array}{l}\text { Screening low acuity ED patients } \\
\text { for mental health concerns } \\
\text { may be useful, though studies } \\
\text { assessing the impact of screening } \\
\text { on patient-oriented outcomes are } \\
\text { needed. }\end{array}$ \\
\hline
\end{tabular}




\begin{tabular}{|c|c|c|c|c|c|c|c|}
\hline Citation & $\begin{array}{l}\text { Quality } \\
\text { Grade }\end{array}$ & Question & Search Strategy & \begin{tabular}{|l} 
Inclusion/ \\
Exclusion \\
Criteria
\end{tabular} & $\begin{array}{l}\text { Data Extraction and } \\
\text { Analysis }\end{array}$ & Key Findings & $\begin{array}{l}\text { Usefulness/Recommendation/ } \\
\text { Implications }\end{array}$ \\
\hline & & & & & $\begin{array}{l}\text { Where not available, } \\
\text { relative risk was } \\
\text { calculated using } \\
\text { the MEDCALC } \\
\text { relative risk statistical } \\
\text { calculator. }\end{array}$ & & \\
\hline $\begin{array}{l}\text { Hoftra et al., } \\
2020\end{array}$ & $\begin{array}{l}\text { Grade: B } \\
\text { Moderate }\end{array}$ & $\begin{array}{l}\text { Will early } \\
\text { intervention be } \\
\text { effective in } \\
\text { limiting } \\
\text { suicide } \\
\text { attempts? }\end{array}$ & $\begin{array}{l}\text { A search was performed } \\
\text { of systematic reviews of } \\
\text { randomised or } \\
\text { controlled studies in the } \\
\text { field of suicide } \\
\text { prevention interventions } \\
\text { with MeSH terms and } \\
\text { free text terms for } \\
\text { 'suicide prevention' and } \\
\text { 'inter-ention' and } \\
\text { 'systematic review'. A } \\
\text { second search was run } \\
\text { with 'suicide } \\
\text { prevention' and } \\
\text { 'intervention' and } \\
\text { 'clinical trial'. }\end{array}$ & $\begin{array}{l}\text { Suicide attempts } \\
\text { were included as } \\
\text { an outcome and if } \\
\text { a suicide } \\
\text { prevention } \\
\text { intervention } \\
\text { was compared } \\
\text { with a control } \\
\text { group or period. } \\
\text { Studies were } \\
\text { included } \\
\text { when } \\
\text { randomisation } \\
\text { was performed } \\
\text { between patients } \\
\text { or between } \\
\text { practice settings. } \\
\text { The exclusion } \\
\text { criterion was the } \\
\text { inclusion of self- } \\
\text { harm (non-sui- } \\
\text { cidal self-injury; } \\
\text { SH) in the target } \\
\text { group for the } \\
\text { intervention. }\end{array}$ & $\begin{array}{l}\text { The extraction of } \\
\text { data was performed } \\
\text { independently by two } \\
\text { researchers (EH and } \\
\text { DÖ). In } \\
\text { the case of non- } \\
\text { consensus, a third } \\
\text { assessor (CFC) was } \\
\text { consulted to make } \\
\text { the final decision. } \\
\text { Cohen's delta was } \\
\text { calculated by a } \\
\text { random meta-analysis } \\
\text { on completed and } \\
\text { attempted } \\
\text { suicides as outcomes. } \\
\text { Meta-regression } \\
\text { explored a possible } \\
\text { synergistic effect in } \\
\text { multilevel } \\
\text { interventions. }\end{array}$ & $\begin{array}{l}\text { A significant } \\
\text { effect was found } \\
\text { for suicide } \\
\text { prevention } \\
\text { interventions on } \\
\text { completed } \\
\text { suicides and on } \\
\text { suicide attempts } \\
\text { Regarding the } \\
\text { synergistic effect } \\
\text { of multilevel } \\
\text { interventions, } \\
\text { meta-regression } \\
\text { showed a } \\
\text { significantly } \\
\text { higher effect } \\
\text { related to the } \\
\text { number of levels } \\
\text { of the } \\
\text { intervention. }\end{array}$ & $\begin{array}{l}\text { Suicide prevention interventions } \\
\text { are effective in preventing } \\
\text { completed and attempted suicides } \\
\text { and should be widely } \\
\text { implemented. }\end{array}$ \\
\hline $\begin{array}{l}\text { Schmutte, } \\
\text { Olfson, Xie \& } \\
\text { Marcus, } \\
(2020) .\end{array}$ & $\begin{array}{l}\text { Grade: B } \\
\text { Moderate }\end{array}$ & $\begin{array}{l}\text { Who is more } \\
\text { likely to be } \\
\text { disgnosed with } \\
\text { mental }\end{array}$ & $\begin{array}{l}\text { The study made use of } \\
\text { outpatient and carrier } \\
\text { files contain }\end{array}$ & $\begin{array}{l}\text { Patient-level } \\
\text { independent } \\
\text { variables included } \\
\text { age, sex, and }\end{array}$ & $\begin{array}{l}\text { The cohort was } \\
\text { extracted from } 2015 \\
\text { national claimsfrom } \\
\text { the Medicare Provider }\end{array}$ & $\begin{array}{l}\text { Retrospective } \\
\text { cohort analysis } \\
\text { using } 2015 \\
\text { Medicare claims }\end{array}$ & $\begin{array}{l}\text { Encounters for SA and SI were } \\
\text { less likely than those for DSH to } \\
\text { be dis-charged to the community. } \\
\text { Among community discharges, SA }\end{array}$ \\
\hline
\end{tabular}




\begin{tabular}{|c|c|c|c|c|c|c|c|}
\hline$\overline{\text { Citation }}$ & $\begin{array}{l}\text { Quality } \\
\text { Grade }\end{array}$ & Question & Search Strategy & $\begin{array}{l}\text { Inclusion/ } \\
\text { Exclusion } \\
\text { Criteria }\end{array}$ & \begin{tabular}{|l|} 
Data Extraction and \\
Analysis
\end{tabular} & Key Findings & $\begin{array}{l}\text { Usefulness/Recommendation/ } \\
\text { Implications }\end{array}$ \\
\hline & & $\begin{array}{l}\text { disorder } \\
\text { between those } \\
\text { wilth DSH and } \\
\text { those with SI? }\end{array}$ & $\begin{array}{l}\text { all claims submitted as } \\
\text { nonadmission } \\
\text { (outpatient) } \\
\text { services. Both files } \\
\text { include demographic } \\
\text { information, } \\
\text { date of service, and } \\
\text { diagnoses codes. } \\
\text { Additional data on } \\
\text { regional-level } \\
\text { characteristics of } \\
\text { counties in which } \\
\text { patients resided were } \\
\text { obtained from the Area } \\
\text { Health } \\
\text { Resources File. }\end{array}$ & \begin{tabular}{|l|} 
race/ethnicity. \\
Severity of \\
Medical \\
comorbidity was \\
evaluated with \\
the Elix-hauser \\
Comorbidity \\
Scale, excluding \\
mental health \\
and substance use \\
disorders.
\end{tabular} & \begin{tabular}{|l|} 
Analysis and \\
Review(MedPAR), \\
outpatient, and carrier \\
files. The MedPAR \\
file includes all claims \\
for ED visits that \\
resulted in \\
inpatient stays. \\
\end{tabular} & \begin{tabular}{|l|} 
for adults $\geq 65$ \\
years of age with \\
suicide-related \\
emergency \\
encounters \\
(N = 52,383). \\
Demographic, \\
clinical, and \\
service use \\
characteristics \\
from claimswere \\
merged with \\
county-level Area \\
Health Resource \\
File data. Rates \\
and adjusted risk \\
ratios were \\
assessed for \\
discharge to the \\
community, \\
mental \\
health diagnosis in \\
the emergency \\
department, and \\
outpatient mental \\
health visits with \\
30 days after the \\
emergency \\
encounter.
\end{tabular} & $\begin{array}{l}\text { and SI encounters were more } \\
\text { likely than DSH encounters to be } \\
\text { diagnosed with a mental disorder } \\
\text { in the emergency department. } \\
\text { Encounters for SA and SI were } \\
\text { also more likely than DSH } \\
\text { encounters to receive follow-up } \\
\text { mental care. }\end{array}$ \\
\hline $\begin{array}{l}\text { McBride, Braz } \\
\& \text { Jones, } 2018 .\end{array}$ & $\begin{array}{l}\text { Grade B } \\
\text { Moderate }\end{array}$ & $\begin{array}{l}\text { Is there any } \\
\text { benefit in } \\
\text { screening ED } \\
\text { patients with } \\
\text { low acuity for } \\
\text { mental health } \\
\text { issues? }\end{array}$ & \begin{tabular}{|l|} 
Prospective cross- \\
sectional survey study \\
was performed \\
in the Cooper \\
University Hospital ED, \\
an urban academic \\
department.
\end{tabular} & \begin{tabular}{|l|} 
Patients were \\
eligible for \\
participation if \\
they were aged \\
18 years or older \\
and had an \\
Emergency \\
\end{tabular} & \begin{tabular}{|l|} 
Participants completed \\
two previously \\
validated mental \\
health screening \\
instruments, the \\
Patient Health \\
Questionnaire
\end{tabular} & $\begin{array}{l}\text { It was found out } \\
\text { that of } 816 \\
\text { participants, } 11 \% \\
\text { were at high risk } \\
\text { for suicide. Many } \\
\text { were receptive to } \\
\text { addressing mental }\end{array}$ & $\begin{array}{l}\text { Screening low acuity ED patients } \\
\text { for mental health concerns } \\
\text { may be useful, though studies } \\
\text { assessing the impact of screening } \\
\text { on patient-oriented outcomes are } \\
\text { needed. }\end{array}$ \\
\hline
\end{tabular}




\begin{tabular}{|c|c|c|c|c|c|c|c|}
\hline Citation & $\begin{array}{l}\text { Quality } \\
\text { Grade }\end{array}$ & Question & Search Strategy & \begin{tabular}{|l} 
Inclusion/ \\
Exclusion \\
Criteria
\end{tabular} & $\begin{array}{l}\text { Data Extraction and } \\
\text { Analysis }\end{array}$ & Key Findings & $\begin{array}{l}\text { Usefulness/Recommendation/ } \\
\text { Implications }\end{array}$ \\
\hline & & & & $\begin{array}{l}\text { Severity Index } \\
\text { (ESI) triage score } \\
\text { of } 4 \text { or } 5 \text {. Patients } \\
\text { were excluded if } \\
\text { they did not speak } \\
\text { English, if } \\
\text { theysuffered from } \\
\text { dementia or other } \\
\text { cognitive } \\
\text { impairment, if } \\
\text { they presented to } \\
\text { the ED for } \\
\text { treatment of an } \\
\text { acute psychiatric } \\
\text { emergency, if } \\
\text { they were } \\
\text { intoxicated, or if } \\
\text { they were } \\
\text { incarcerated at } \\
\text { the time of their } \\
\text { ED visit. }\end{array}$ & $\begin{array}{l}\text { for Depression and } \\
\text { Anxiety (PHQ-4) and } \\
\text { the Suicide Behaviors } \\
\text { Questionnaire-- } \\
\text { Revised (SBQ- } \\
\text { R).10,11 The PHQ-4 } \\
\text { has been validated as } \\
\text { a screening tool for } \\
\text { depression and } \\
\text { anxiety in both } \\
\text { general and primary- } \\
\text { care populations. } \\
\text { Descriptive data are } \\
\text { presented, including } \\
\text { proportions, median } \\
\text { with interquartile } \\
\text { range, and mean with } \\
\text { standard deviation. } \\
\text { Chi-square test was } \\
\text { used to compare data } \\
\text { between categorical } \\
\text { variables. P values < } \\
\text { 0.05 were considered } \\
\text { statistically } \\
\text { significant, }\end{array}$ & $\begin{array}{l}\text { health issues } \\
\text { during the ED } \\
\text { visit. }\end{array}$ & \\
\hline $\begin{array}{l}\text { Grumet, } \\
\text { Hogan, Chu, } \\
\text { Covington, \& } \\
\text { Johnson, } 2019 .\end{array}$ & $\begin{array}{l}\text { Grade C } \\
\text { Low }\end{array}$ & $\begin{array}{l}\text { What is the } \\
\text { impact of } \\
\text { ZERO Suicide } \\
\text { on mental } \\
\text { health } \\
\text { patients? }\end{array}$ & Not Stated & $\begin{array}{l}\text { Systematic } \\
\text { identification and } \\
\text { assessment of } \\
\text { suicide risk } \\
\text { among people } \\
\text { receiving care. }\end{array}$ & $\begin{array}{l}\text { Secondary Data. } \\
\text { Qualitative and } \\
\text { Descriptive review of } \\
\text { literatures were } \\
\text { employed. }\end{array}$ & $\begin{array}{l}\text { Every minute of } \\
\text { every day suicide } \\
\text { is impacting the } \\
\text { lives of hundreds } \\
\text { of people across } \\
\text { the nation. It robs } \\
\text { us of our family, } \\
\text { friends, } \\
\text { colleagues, and } \\
\text { our community's } \\
\text { most }\end{array}$ & $\begin{array}{l}\text { Medical and clinical professionals } \\
\text { have always saved lives, but Zero } \\
\text { Suicide shows they can have a far } \\
\text { deeper impact. }\end{array}$ \\
\hline
\end{tabular}




\begin{tabular}{|c|c|c|c|c|c|c|c|}
\hline Citation & $\begin{array}{l}\text { Quality } \\
\text { Grade }\end{array}$ & Question & Search Strategy & \begin{tabular}{|l|} 
Inclusion/ \\
Exclusion \\
Criteria
\end{tabular} & $\begin{array}{l}\text { Data Extraction and } \\
\text { Analysis }\end{array}$ & Key Findings & $\begin{array}{l}\text { Usefulness/Recommendation/ } \\
\text { Implications }\end{array}$ \\
\hline & & & & & & $\begin{array}{l}\text { valuable resource, } \\
\text { our people. }\end{array}$ & \\
\hline $\begin{array}{l}\text { Meerwijk, } \\
\text { Parekh, } \\
\text { Oquendo, } \\
\text { Allen, Franck } \\
\text { \& Lee, } 2016 .\end{array}$ & $\begin{array}{l}\text { Grade A } \\
\text { High }\end{array}$ & $\begin{array}{l}\text { Is there any } \\
\text { benefit in } \\
\text { utilizing direct } \\
\text { interventions } \\
\text { in reducing } \\
\text { suicidality } \\
\text { among patients } \\
\text { with suicidal } \\
\text { thoughts? }\end{array}$ & $\begin{array}{l}\text { MEDLINE and } \\
\text { PsycINFO were } \\
\text { searched from inception } \\
\text { to Dec } 25,2015, \text { for } \\
\text { randomised controlled } \\
\text { trials that reported } \\
\text { suicides or suicide } \\
\text { attempts as an outcome, } \\
\text { irrespective of partici- } \\
\text { pants' diagnoses or the } \\
\text { publication language. }\end{array}$ & $\begin{array}{l}\text { There were } \\
\text { exclusion of } \\
\text { studies with } \\
\text { pharma- } \\
\text { cological or } \\
\text { device-based } \\
\text { interventions, } \\
\text { those that targeted } \\
\text { communities or } \\
\text { clinicians, } \\
\text { primary } \\
\text { prevention trials, } \\
\text { and trials that } \\
\text { reported events of } \\
\text { non-suicidal self- } \\
\text { injury as suicide } \\
\text { attempts. }\end{array}$ & \begin{tabular}{|l|} 
For the systematic \\
review and meta- \\
analysis, MEDLINE \\
and PsycINFO were \\
searched from \\
inception to Dec 25, \\
2015, for randomised \\
controlled trials \\
that reported suicides \\
or suicide attempts as \\
an outcome, \\
irrespective of partici- \\
pants' diagnoses or the \\
publication language. \\
Random-effects \\
models of the odds \\
ratio was used (OR) \\
based on a pooled \\
measure of suicides \\
and the number of \\
individuals who \\
attempted suicide, \\
immediately post- \\
treatment and at \\
longer-term follow- \\
up.
\end{tabular} & \begin{tabular}{|l|} 
Of 2024 unique \\
abstracts screened, \\
53 articles met \\
eligibility criteria \\
and \\
reported on 44 \\
studies; 31 studies \\
provided post- \\
treatment data \\
with 6658 \\
intervention group \\
participants and \\
6711 control \\
group participants \\
at baseline, and 29 \\
studies provided \\
follow-up data. \\
The post- \\
treatment \\
difference \\
between direct \\
interventions and \\
indirect \\
interventions did \\
not reach \\
statistical \\
significance at the \\
0.05 level.
\end{tabular} & $\begin{array}{l}\text { It is recommended that clinicians } \\
\text { utilise direct interventions that } \\
\text { include discussing a client's } \\
\text { suicidal thoughts and behaviors, as } \\
\text { well as strategies to reduce } \\
\text { suicidality. }\end{array}$ \\
\hline \begin{tabular}{|l} 
Roaten, \\
Johnson, \\
Genzel, Khan, \\
\& North, 2018.
\end{tabular} & $\begin{array}{l}\text { Grade B } \\
\text { Good }\end{array}$ & $\begin{array}{l}\text { How could } \\
\text { universal } \\
\text { screening help } \\
\text { to limit suicide }\end{array}$ & $\begin{array}{l}\text { The steps in developing } \\
\text { and implementing this } \\
\text { evidence-based practice } \\
\text { change program were }\end{array}$ & $\begin{array}{l}\text { There were } \\
\text { exclusion of } \\
\text { studies with } \\
\text { pharmacological }\end{array}$ & $\begin{array}{l}\text { Prevalence data on } \\
\text { suicide risk levels are } \\
\text { provided for } 328,064 \\
\text { adult encounters from }\end{array}$ & $\begin{array}{l}\text { Approximately } \\
\text { half of the screens } \\
\text { were completed in } \\
\text { the outpatient }\end{array}$ & $\begin{array}{l}\text { This article describes } \\
\text { implementation of a universal } \\
\text { suicide screening program in a } \\
\text { large safety-net health care system, }\end{array}$ \\
\hline
\end{tabular}




\begin{tabular}{|c|c|c|c|c|c|c|c|}
\hline Citation & $\begin{array}{l}\text { Quality } \\
\text { Grade }\end{array}$ & Question & Search Strategy & \begin{tabular}{|l} 
Inclusion/ \\
Exclusion \\
Criteria
\end{tabular} & $\begin{array}{l}\text { Data Extraction and } \\
\text { Analysis }\end{array}$ & Key Findings & $\begin{array}{l}\text { Usefulness/Recommendation/ } \\
\text { Implications }\end{array}$ \\
\hline & & \begin{tabular}{|l|} 
attempt in \\
patients who \\
present for \\
nonbehavioral \\
health care \\
issues? \\
\end{tabular} & $\begin{array}{l}\text { gathering intelligence, } \\
\text { examining resources, } \\
\text { designing the screening } \\
\text { program, creating a } \\
\text { clinical response, } \\
\text { constructing an } \\
\text { electronic health record } \\
\text { screening protocol, } \\
\text { clinical workforce } \\
\text { education, and program } \\
\text { implementation. }\end{array}$ & $\begin{array}{l}\text { or device-based } \\
\text { interventions. }\end{array}$ & $\begin{array}{l}\text { the first six months of } \\
\text { the screening } \\
\text { program. } \\
\text { Columbia-Suicide } \\
\text { Severity Rating Scale, } \\
\text { Clinical Practice } \\
\text { Screener-Recent, and } \\
\text { a preliminary clinical } \\
\text { decision support } \\
\text { system. }\end{array}$ & $\begin{array}{l}\text { clinics, more than } \\
40 \% \text { in the } \\
\text { emergency } \\
\text { department (ED), } \\
\text { and slightly less } \\
\text { than } 5 \% \text { in the } \\
\text { hospital inpatient } \\
\text { units. In the ED, } \\
6.3 \% \text { of the } \\
\text { screens were } \\
\text { positive, as were } \\
1.6 \% \text { in the } \\
\text { inpatient units, } \\
\text { and } 2.1 \% \text { in the } \\
\text { outpatient clinics. }\end{array}$ & $\begin{array}{l}\text { presents important data that may } \\
\text { be used to address identified needs } \\
\text { for expanded suicide risk } \\
\text { screening, particularly in } \\
\text { nonpsychiatric medical settings } \\
\text { such as primary care clinics and } \\
\text { EDs. }\end{array}$ \\
\hline $\begin{array}{l}\text { Drapeau et al., } \\
2019 .\end{array}$ & $\begin{array}{l}\text { Quality } \\
\text { Good } \\
\text { Grade B }\end{array}$ & $\begin{array}{l}\text { What rate of } \\
\text { patients had } \\
\text { contact with a } \\
\text { physician } \\
\text { within the year } \\
\text { prior to fatally } \\
\text { attempting } \\
\text { suicide? }\end{array}$ & $\begin{array}{l}\text { A literature review of } \\
\text { suicide risk screening } \\
\text { and assessment studies } \\
\text { identified through Psy- } \\
\text { chINFO, } \\
\text { MEDLINE/PubMed, } \\
\text { and Google Scholar. }\end{array}$ & $\begin{array}{l}\text { The papers } \\
\text { included in this } \\
\text { review were peer- } \\
\text { reviewed and } \\
\text { published in } \\
\text { English. } \\
\text { Articles that did } \\
\text { not focus on the } \\
\text { screening or } \\
\text { assessment of } \\
\text { suicide risk were } \\
\text { discarded. }\end{array}$ & $\begin{array}{l}\text { It is a qualitative } \\
\text { review of literatures. }\end{array}$ & $\begin{array}{l}\text { Sleep disturbances } \\
\text { in general are both } \\
\text { a risk factor and } \\
\text { potential warning } \\
\text { sign for suicide. } \\
\text { Not all patients } \\
\text { presenting with } \\
\text { suicide risk will } \\
\text { have a history of } \\
\text { psychiatric illness. }\end{array}$ & $\begin{array}{l}\text { Using evidence-based risk } \\
\text { screening tools, such as the } \\
\text { Columbia suicide severity rating } \\
\text { scale (C-SSRS), is rec- } \\
\text { ommended despite insufficient } \\
\text { evidence to date on the outcomes } \\
\text { of suicide risk screening. It is } \\
\text { recommended that sleep clinicians } \\
\text { be aware of idiosyncratic instances } \\
\text { of emergent suicide risk that could } \\
\text { result as part of standard care and } \\
\text { monitor patient access to } \\
\text { hypnotic medications during high- } \\
\text { risk periods due to } \\
\text { increased risk for inducing } \\
\text { parasomnia and self-injurious } \\
\text { behavior. } \\
\text { For sleep clinic professionals who } \\
\text { do not have the time to } \\
\text { comprehensively assess and } \\
\text { manage suicide risk, }\end{array}$ \\
\hline
\end{tabular}




\begin{tabular}{|c|c|c|c|c|c|c|c|}
\hline Citation & $\begin{array}{l}\text { Quality } \\
\text { Grade }\end{array}$ & Question & Search Strategy & \begin{tabular}{|l} 
Inclusion/ \\
Exclusion \\
Criteria
\end{tabular} & $\begin{array}{l}\text { Data Extraction and } \\
\text { Analysis }\end{array}$ & Key Findings & $\begin{array}{l}\text { Usefulness/Recommendation/ } \\
\text { Implications }\end{array}$ \\
\hline & & & & & & & $\begin{array}{l}\text { implementing suicide prevention } \\
\text { policies within their } \\
\text { departments/clinics is } \\
\text { recommended, along with } \\
\text { following the best available } \\
\text { evidence to inform these policies }\end{array}$ \\
\hline $\begin{array}{l}\text { Boudreaux et } \\
\text { a1., } 2016\end{array}$ & $\begin{array}{l}\text { Quality: } \\
\text { Good } \\
\text { Grade: B }\end{array}$ & $\begin{array}{l}\text { What is the } \\
\text { most effective } \\
\text { way to } \\
\text { examine } \\
\text { whether } \\
\text { universal } \\
\text { suicide risk } \\
\text { screening is } \\
\text { feasible and } \\
\text { effective at } \\
\text { improving } \\
\text { suicide risk } \\
\text { detection in the } \\
\text { emergency } \\
\text { department? }\end{array}$ & $\begin{array}{l}\text { Medical records and } \\
\text { interview method. }\end{array}$ & Not Stated & $\begin{array}{l}\text { Across all phases, } \\
\text { sites staffed the ED } \\
\text { with research } \\
\text { assistants } \\
\text { (RAs) at least } 40 \\
\text { hours/week during } \\
\text { peak volume hours } \\
\text { (12NOON to } \\
10: 00 P M), \text { with at } \\
\text { least } 1 \text { weekend } \\
\text { day/month. As both } \\
\text { volume and } \\
\text { enrollment rates } \\
\text { decline after } \\
10: 00 P M \text {. Across all } \\
\text { phases, sites staffed } \\
\text { the ED with research } \\
\text { assistants (RAs) at } \\
\text { least } 40 \text { hours/week } \\
\text { during peak volume } \\
\text { hours (12NOON } \\
\text { to } 10: 00 P M), \text { with at } \\
\text { least } 1 \text { weekend } \\
\text { day/month. As both } \\
\text { volume and } \\
\text { enrollment rates } \\
\text { decline after } \\
10: 00 \text { PM. Analyses } \\
\text { were performed using }\end{array}$ & $\begin{array}{l}\text { Across the three } \\
\text { phases } \\
\text { (N1/4236,791 ED } \\
\text { visit records), } \\
\text { documented } \\
\text { screenings rose } \\
\text { from } \\
26 \% \text { (Phase 1) to } \\
84 \% \text { (Phase 3) } \\
\text { Detection rose } \\
\text { from } 2.9 \% \text { to } \\
5.7 \% \text {. The } \\
\text { majority of } \\
\text { detected } \\
\text { intentional self- } \\
\text { harm was } \\
\text { confirmed as } \\
\text { recent suicidal } \\
\text { ideation or } \\
\text { behavior by } \\
\text { patient interview. }\end{array}$ & $\begin{array}{l}\text { Universal suicide risk screening in } \\
\text { the ED was feasible and led to a } \\
\text { nearly twofold increase in risk } \\
\text { detection. If these findings remain } \\
\text { true when scaled, the public health } \\
\text { impact could be tremendous, } \\
\text { because identification of risk is the } \\
\text { first and necessary step for } \\
\text { preventing suicide. }\end{array}$ \\
\hline
\end{tabular}


REDUCING PATIENT RISK FOR SUICIDAL BEHAVIOR

62

\begin{tabular}{|l|l|l|l|l|l|l|}
\hline Citation & $\begin{array}{l}\text { Quality } \\
\text { Grade }\end{array}$ & Question & Search Strategy & $\begin{array}{l}\text { Inclusion/ } \\
\text { Exclusion } \\
\text { Criteria }\end{array}$ & $\begin{array}{l}\text { Data Extraction and } \\
\text { Analysis }\end{array}$ & $\begin{array}{l}\text { Key Findings } \\
\text { Implications }\end{array}$ \\
\hline & & & $\begin{array}{l}\text { State, version 13.1. } \\
\text { Data are } \\
\text { presented as } \\
\text { proportions with } 95 \% \\
\text { CIs and medians with } \\
\text { interquartile ranges. } \\
\text { Changes in } \\
\text { documentation of } \\
\text { screening and } \\
\text { detection were } \\
\text { evaluated by } \\
\text { analyzing data from } \\
\text { the Screening Log } \\
\text { using chi-square tests. } \\
\text { Analyses were } \\
\text { repeated using random } \\
\text { chart } \\
\text { review data as a } \\
\text { confirmation of } \\
\text { trends. }\end{array}$ \\
\hline
\end{tabular}

Legend: 


\section{Appendix C}

\section{Project Schedule}

\begin{tabular}{|c|c|c|c|c|c|c|c|c|c|c|c|c|c|c|c|c|c|c|c|c|c|c|c|c|}
\hline & \multicolumn{8}{|c|}{ NUR7801 } & \multicolumn{8}{|c|}{ NUR7802 } & \multicolumn{8}{|c|}{ NUR7803 } \\
\hline 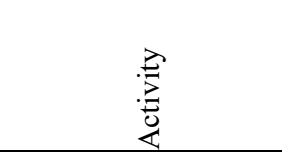 & $\begin{array}{l}7 \\
\frac{\pi}{8} \\
0 \\
3\end{array}$ & $\begin{array}{l}m \\
\frac{m}{8} \\
3 \\
3\end{array}$ & $\begin{array}{l}n \\
\frac{4}{8} \\
3 \\
3\end{array}$ & $\frac{5}{3}$ & $\begin{array}{l}\frac{9}{8} \\
0 \\
0\end{array}$ & $\begin{array}{l}= \\
\frac{y}{8} \\
\frac{0}{3}\end{array}$ & $\begin{array}{l}\frac{m}{2} \\
\frac{y}{0} \\
3\end{array}$ & $\begin{array}{l}\frac{n}{1} \\
\frac{y}{8} \\
3 \\
3\end{array}$ & $\frac{-7}{3}$ & $\begin{array}{l}m \\
\frac{n}{0} \\
3 \\
3\end{array}$ & $\begin{array}{l}n \\
\frac{n}{0} \\
\frac{0}{3}\end{array}$ & $\frac{5}{3}$ & $\begin{array}{l}\frac{9}{10} \\
\frac{1}{3}\end{array}$ & $\begin{array}{l}= \\
\frac{y}{0} \\
3 \\
3\end{array}$ & $\begin{array}{l}\frac{m}{4} \\
\frac{\pi}{8} \\
3\end{array}$ & $\begin{array}{l}n \\
\frac{n}{8} \\
\frac{1}{3}\end{array}$ & $\frac{\bar{y}}{3}$ & $\begin{array}{l}m \\
\frac{4}{8} \\
3 \\
3\end{array}$ & $\begin{array}{l}n \\
\frac{1}{0} \\
3 \\
3\end{array}$ & $\begin{array}{l}\frac{y}{8} \\
\frac{1}{3} \\
3\end{array}$ & $\begin{array}{l}a \\
\frac{1}{0} \\
3\end{array}$ & $\begin{array}{l}= \\
\frac{y}{8} \\
3\end{array}$ & $\begin{array}{l}\frac{n}{y} \\
\frac{y}{0} \\
3\end{array}$ & $\begin{array}{l}\frac{n}{4} \\
\frac{y}{8} \\
\frac{d}{3}\end{array}$ \\
\hline Meet with preceptor & $\mathrm{x}$ & $\mathrm{x}$ & $\mathrm{x}$ & $\mathrm{x}$ & $\mathrm{x}$ & $\mathrm{x}$ & $\mathrm{x}$ & & $\mathrm{x}$ & & $\mathrm{x}$ & $\mathrm{x}$ & $\mathrm{x}$ & $\mathrm{x}$ & $\mathrm{x}$ & $\mathrm{x}$ & & $\mathrm{x}$ & & $\mathrm{x}$ & & $\mathrm{x}$ & & $\mathrm{x}$ \\
\hline $\begin{array}{l}\text { Prepare project } \\
\text { proposal }\end{array}$ & $\mathrm{x}$ & $\mathrm{x}$ & & & & & & & & & & & & & & & & & & & & & & \\
\hline $\begin{array}{l}\text { Collaborate with } \\
\text { key stakeholders }\end{array}$ & & $\mathrm{x}$ & & $\mathrm{x}$ & & $\mathrm{x}$ & $\mathrm{x}$ & & $\mathrm{x}$ & & $\mathrm{x}$ & & & $\mathrm{x}$ & & $\mathrm{x}$ & $\mathrm{x}$ & $\mathrm{x}$ & & $\mathrm{x}$ & & $\mathrm{x}$ & & $\mathrm{x}$ \\
\hline $\begin{array}{l}\text { Prepare project } \\
\text { proposal and plan } \\
\text { intervention }\end{array}$ & & & & & & $\mathrm{x}$ & $\mathrm{x}$ & $\mathrm{x}$ & & & & & & & & & & & & & & & & \\
\hline $\begin{array}{l}\text { Collaborate with } \\
\text { interprofessional } \\
\text { leadership team }\end{array}$ & & & & & & $\mathrm{x}$ & $\mathrm{x}$ & $\mathrm{x}$ & & & & & & & & & & & & & & & & \\
\hline $\begin{array}{l}\text { Create mission and } \\
\text { vision }\end{array}$ & & & & & & $\mathrm{x}$ & $\mathrm{x}$ & & & & & & & & & & & & & & & & & \\
\hline $\begin{array}{l}\text { Prepare IRB and } \\
\text { proposal }\end{array}$ & & & & & & & & $\mathrm{x}$ & $\mathrm{x}$ & $\mathrm{x}$ & & & & & & & & & & & & & & \\
\hline $\begin{array}{l}\text { Communicate } \\
\text { mission and vision } \\
\text { to leadership team }\end{array}$ & & & & & & & & $\mathrm{x}$ & $\mathrm{x}$ & $\mathrm{x}$ & & & & & & & & & & & & & & \\
\hline $\begin{array}{l}\text { Educate and train } \\
\text { providers }\end{array}$ & & & & & & & & & & $\mathrm{x}$ & $\mathrm{x}$ & $\mathrm{x}$ & & & & & & & & & & & & \\
\hline $\begin{array}{l}\text { Disseminate } \\
\text { resources }\end{array}$ & & & & & & & & & & & $\mathrm{x}$ & $\mathrm{x}$ & & & & & & & & & & & & \\
\hline $\begin{array}{l}\text { Implement } \\
\text { intervention }\end{array}$ & & & & & & & & & & & & $\mathrm{x}$ & $\mathrm{x}$ & $\mathrm{x}$ & $\mathrm{x}$ & $\mathrm{x}$ & & & & & & & & \\
\hline $\begin{array}{l}\text { Study and analyze } \\
\text { data for feedback }\end{array}$ & & & & & & & & & & & & & & $\mathrm{x}$ & $\mathrm{x}$ & $\mathrm{x}$ & $\mathrm{x}$ & $\mathrm{x}$ & & & & & & \\
\hline Evaluate project & & & & & & & & & & & & & & & & & & & $\mathrm{x}$ & $\mathrm{x}$ & & & & \\
\hline Give final report & & & & & & & & & & & & & & & & & & & & & $\mathrm{x}$ & $\mathrm{x}$ & & \\
\hline Disseminate result & & & & & & & & & & & & & & & & & & & & & & & $\mathrm{x}$ & $\mathrm{x}$ \\
\hline & & & & & & & & & & & & & & & & & & & & & & & & \\
\hline & & & & & & & & & & & & & & & & & & & & & & & & \\
\hline & & & & & & & & & & & & & & & & & & & & & & & & \\
\hline
\end{tabular}




\begin{tabular}{|c|c|c|c|c|c|c|c|c|c|c|c|c|c|c|c|c|c|c|c|c|c|c|c|c|}
\hline \multirow[b]{2}{*}{$\underbrace{2}_{0}$} & \multicolumn{8}{|c|}{ NUR7801 } & \multicolumn{8}{|c|}{ NUR7802 } & \multicolumn{8}{|c|}{ NUR7803 } \\
\hline & 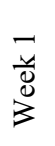 & $\begin{array}{l}\frac{m}{\tilde{J}} \\
\frac{\tilde{d}}{3} \\
\frac{3}{3}\end{array}$ & $\begin{array}{l}n \\
\frac{n}{8} \\
3 \\
3\end{array}$ & $\begin{array}{l}\bar{y} \\
\frac{\tilde{y}}{3} \\
3\end{array}$ & $\begin{array}{l}\stackrel{\partial}{0} \\
\frac{0}{3}\end{array}$ & $\begin{array}{l}\bar{\Xi} \\
\bar{d} \\
\vec{\delta}\end{array}$ & $\begin{array}{l}\frac{m}{u} \\
\frac{u}{\Delta} \\
3\end{array}$ & $\begin{array}{l}n \\
\frac{u}{0} \\
\frac{\pi}{3}\end{array}$ & $\begin{array}{l}\overline{\breve{u}} \\
\bar{d} \\
\overrightarrow{3}\end{array}$ & $\frac{m}{\frac{m}{\ddot{y}}}$ & $\begin{array}{l}n \\
\frac{u}{0} \\
3 \\
3\end{array}$ & $\begin{array}{l}\bar{u} \\
\frac{\tilde{J}}{3} \\
3\end{array}$ & $\begin{array}{l}\frac{a}{8} \\
\frac{d}{3}\end{array}$ & $\begin{array}{l}\bar{J} \\
\frac{u}{0} \\
3\end{array}$ & $\begin{array}{l}\frac{m}{u} \\
\frac{u}{0} \\
3\end{array}$ & $\begin{array}{l}n \\
\frac{u}{0} \\
z\end{array}$ & $\begin{array}{l}\vec{u} \\
\frac{\pi}{8} \\
3\end{array}$ & $\begin{array}{l}\frac{m}{u} \\
\frac{u}{\tilde{d}} \\
3\end{array}$ & $\begin{array}{l}n \\
\frac{n}{8} \\
z^{3}\end{array}$ & $\begin{array}{l}\bar{y} \\
\frac{0}{0} \\
3\end{array}$ & 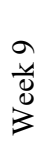 & $\begin{array}{l}\bar{J} \\
\frac{u}{0} \\
3\end{array}$ & $\begin{array}{l}\frac{m}{u} \\
\frac{u}{\Delta} \\
3\end{array}$ & $\begin{array}{l}\frac{n}{4} \\
\frac{4}{8} \\
3\end{array}$ \\
\hline & & & & & & & & & & & & & & & & & & & & & & & & \\
\hline & & & & & & & & & & & & & & & & & & & & & & & & \\
\hline & & & & & & & & & & & & & & & & & & & & & & & & \\
\hline & & & & & & & & & & & & & & & & & & & & & & & & \\
\hline
\end{tabular}




\section{Appendix D}

\section{Data Collection Tool for Evaluation}

\section{Columbia- Suicide Severity Rating Scale}

\section{Demographic Data:}

Participant's ID \#

Age:

Gender:

Ethnicity

Highest Education

Employment Status

Participant's Demographic Table

\begin{tabular}{|c|c|c|c|c|c|c|c|}
\hline 4 & A & B & C & $\mathrm{D}$ & $\mathrm{E}$ & $\mathrm{F}$ & G \\
\hline 1 & Questions & Variables & Value & Missing Data -99 & & & \\
\hline 2 & ID\# & Self-Generated & & & & & \\
\hline \multicolumn{8}{|c|}{3} \\
\hline \multicolumn{8}{|l|}{4} \\
\hline 5 & 1. What is your gender & Gender & $0=$ Female & & & & \\
\hline 6 & & & $1=$ Male & & & & \\
\hline \multicolumn{8}{|l|}{7} \\
\hline 8 & 2. Age range & Age & $0=18$ to 25 & & & & \\
\hline 9 & & & $1=26$ to 35 & & & & \\
\hline 10 & & & $2=35$ to 45 & & & & \\
\hline 11 & & & $3=45$ to 55 & & & & \\
\hline 12 & & & $4=56$ to 65 & & & & \\
\hline 13 & & & $5=$ over 66 & & & & \\
\hline \multicolumn{8}{|l|}{14} \\
\hline 15 & 3. Highest level of education & Education & $0=$ Elementary & & & & \\
\hline 16 & & & 1= High School & & & & \\
\hline 17 & & & $2=$ Some College & & & & \\
\hline 18 & & & 3= Bachelor's & & & & \\
\hline 19 & & & 4= Master's & & & & \\
\hline 20 & & & 5= Doctorate or $\mathrm{PhD}$ & & & & \\
\hline \multicolumn{8}{|l|}{21} \\
\hline 22 & 4. Your employment status & Employment & $0=$ Full-time & & & & \\
\hline 23 & & & 1= Part-time & & & & \\
\hline 24 & & & $2=$ Self-employed & & & & \\
\hline 25 & & & 3= Unemployed & & & & \\
\hline 26 & & & 4= Retired & & & & \\
\hline \multicolumn{8}{|l|}{27} \\
\hline 28 & 5. What is your ethnicity? & Ethnicity & $0=$ White & & & & \\
\hline 29 & & & 1= Black, Carribean, African & & & & \\
\hline 30 & & & 2= Latin, Hispanic & & & & \\
\hline 31 & & & 3= American Indian/Alaskan Native & & & & \\
\hline 32 & & & $4=$ Oriental & & & & \\
\hline \multicolumn{8}{|l|}{33} \\
\hline 34 & & & & & & & \\
\hline
\end{tabular}




\begin{tabular}{|c|c|c|c|}
\hline 53 & Suicidal Behavior & & \\
\hline 54 & & & \\
\hline 55 & 11. Have you made a suioide attempt? & Pre 11 & $0=$ No attempts \\
\hline 56 & & & $1=1-3$ attempts \\
\hline 57 & & & $2=4-6$ attempts \\
\hline 58 & & & $3=$ To many to count \\
\hline \multirow[t]{2}{*}{59} & & & \\
\hline & $\begin{array}{l}\text { 12. Has there been a time when you started to do something to end your life but someone or something stopped } \\
\text { you before } \\
\text { you actually did anything }\end{array}$ & Pre 12 & $0=$ No attempts \\
\hline 61 & & & $1=1-3$ attempts \\
\hline 62 & & & $2=4-6$ attempts \\
\hline 63 & & & $3=$ To many to count \\
\hline 64 & & & \\
\hline 65 & $\begin{array}{l}\text { 13. Have you taken any steps tow ards making a suicide attempt or preparing to kill yourself (such as collecting pills, } \\
\text { getting a gun, giving valuables aw ay or writing a suicide note)? }\end{array}$ & Pre 12 & $0=$ No attempts \\
\hline 66 & & & $1=1-3$ attempts \\
\hline 67 & & & $2=4-6$ attempts \\
\hline 68 & & & $3=$ To many to count \\
\hline 69 & & & \\
\hline 70 & 14 & & \\
\hline 71 & & & \\
\hline 72 & & & \\
\hline 73 & & & \\
\hline \multirow{2}{*}{$\begin{array}{l}74 \\
75\end{array}$} & & & \\
\hline & & & \\
\hline \multirow{2}{*}{$\frac{76}{77}$} & & & \\
\hline & & & \\
\hline
\end{tabular}




\section{Appendix E}

\section{C-SSRS Checklist for Nurses}

Nurses Initial:

Date and Time:

\begin{tabular}{|l|l|l|}
\hline & Yes & No \\
\hline Date of Assessment noted & & \\
\hline Screening performed during my shift & & \\
\hline All parts of screening completed & & \\
\hline Patient answered no to all questions & & \\
\hline Patient answered yes to one of the questions & & \\
\hline Patient was observed for non-verbal signs & & \\
\hline Patient was encouraged to verbalize true feelings & & \\
\hline Patient was referred to behavioral team & & \\
\hline Patient will need an ongoing follow up & & \\
\hline
\end{tabular}




\section{Appendix F}

\section{CAMS and SPI Poster}

\begin{tabular}{|l|}
\hline \multicolumn{1}{|c|}{ Collaborative Assessment and Management of Suicidality (CAMS) } \\
\hline Staff will initially meet with patient \\
\hline Obtain permission to sit and talk \\
\hline Encouraging patient to describe their psychological pain, stress. \\
\hline Encouraging patient to describe their agitation, hopelessness, self-hate, and suicide risk. \\
\hline Developing plan to ensure coping skills with current crisis \\
\hline Asking patient for their problem drivers. \\
\hline Documentation will be done on a paper form. \\
\hline Copy of paperwork will be given to patient. \\
\hline Safety Plan Intervention (SPI) \\
\hline Interventions include using distraction \\
\hline Placing patient close to the nurses' station \\
\hline Femoving lethal means \\
\hline
\end{tabular}




\section{Appendix G}

\section{Chart Audit Form}

Date of Audit:

Initials of Auditor:

Number of Participants:

\begin{tabular}{|l|l|l|}
\hline & Yes & No \\
\hline Was suicidal ideation documented? & & \\
\hline Was suicidal behavior documented? & & \\
\hline Was suicide attempt documented? & & \\
\hline Was one on one monitoring initiated? & & \\
\hline Was reassessment done on suicidal patients? & & \\
\hline Was reassessment documented on Suicidal patients & & \\
\hline Was safety bundle implemented? & & \\
\hline Was reassessment performed on suicidal patients? & & \\
\hline Was a list of suicidal items documented? & & \\
\hline Was patient educated on coping skills? & & \\
\hline Was referral for follow up initiated? & & \\
\hline Was there documentation on safety bundle initiated? & & \\
\hline Was there any documentation on details of suicide plans? & & \\
\hline Was there any documentation on incidents reports? & & \\
\hline
\end{tabular}




\title{
Appendix H
}

\section{Brochure for Nurses}

\author{
Using the Columbia-Suicide Severity Rating \\ Scale: Medical-Surgical Patients
}

All nursing staff

\section{Welcome}

II. A brief discussion of the proposed evidence-based practice change project

III. Suicide risk on medical-surgical or telemetry patients

\section{The Columbia-Suicide Severity Rating Scale}

a) Used to measure, identify, and assess individuals at risk for suicide

b) Questions are phrased for interview format or self-report

c) The scale measures four areas: severity of ideation, intensity of ideation, behavior, and lethality

\section{Scoring Range of the Scale}
a) Six categories consisting of yes/no answers
b) Range from category 1: wishing to be dead to completed suicide

\section{Implementation of Safety Bundles on Non-Psychiatric Patients}
a) Establish trust
b) Ensure patient safety (remove potential hazards from room such as cords, silverware, curtains)
c) Notify the charge nurse, physician, initiate behavioral intervention team, and nursing liaison
d) Move patient closer to nursing station (provide a controlled environment)
e) Follow-up care (provide resources etc., before discharge home)
f) Documentation on paper or electronic medical record 


\section{Appendix I}

SWOT Analysis

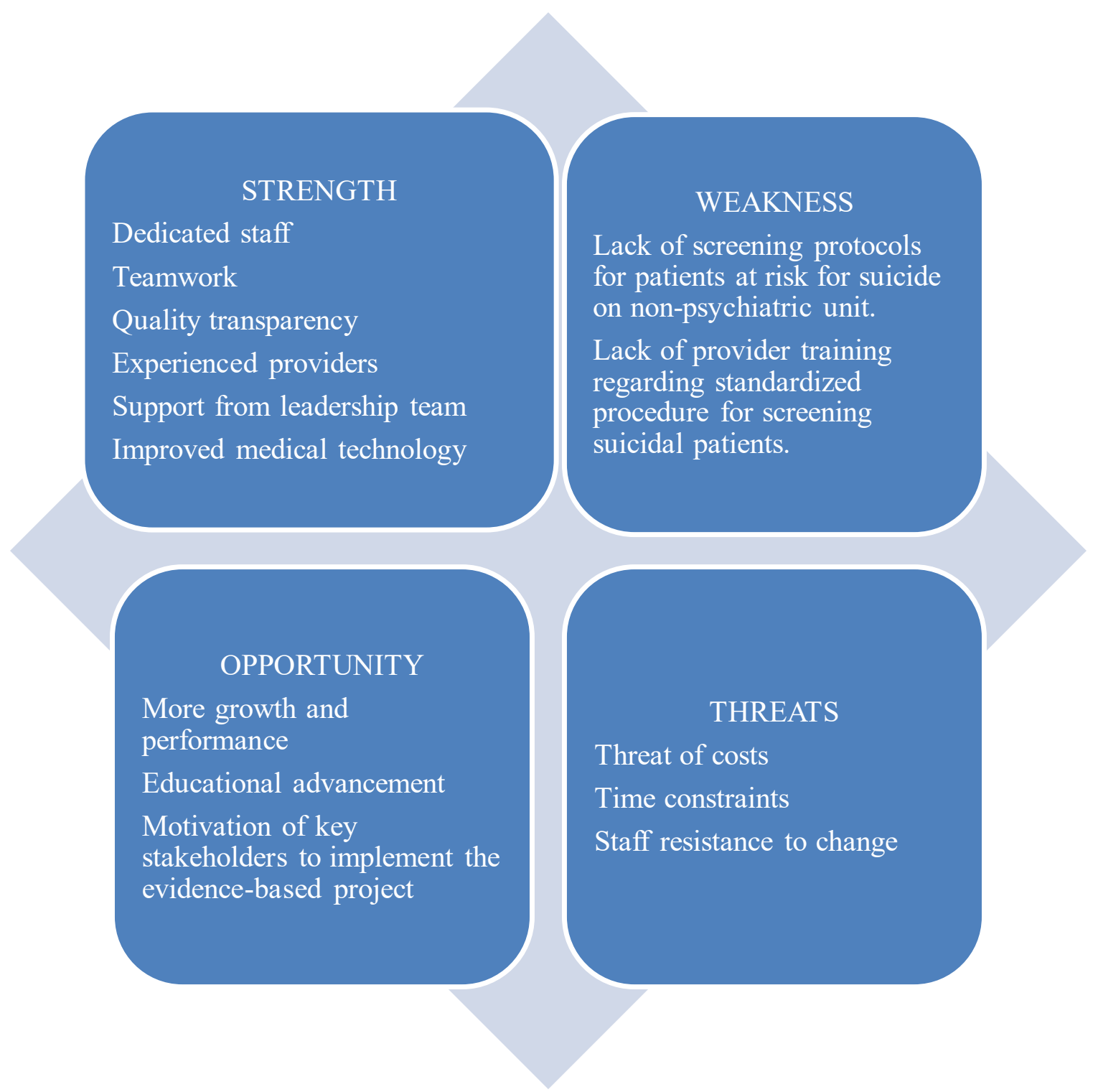




\section{Appendix J}

Hierarchy of Evidence (Concato, Shah \& Horwitz, 2010)

\section{Hierarchy of Evidence}

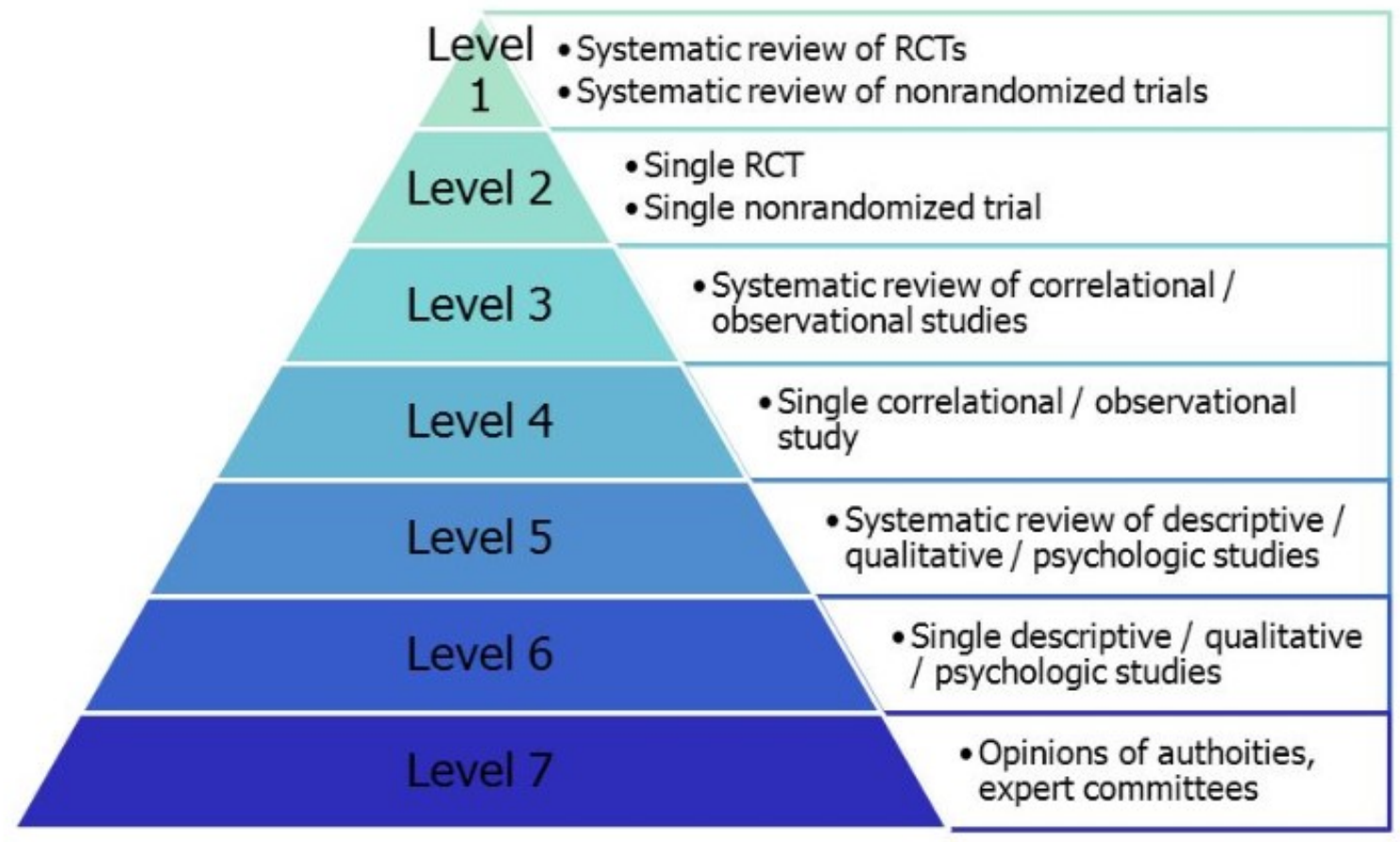




\section{Appendix K}

\begin{tabular}{|c|c|c|c|c|}
\hline Measure & Action & Benchmark & Goal & Data Type \\
\hline Outcome Measure & $\begin{array}{l}\text { The CSSRS Tool helps to identify } \\
\text { patients at risk for suicide }\end{array}$ & $>55 \%$ & $>90 \%$ & Continuous data \\
\hline Outcome Measure & $\begin{array}{l}\text {-Telemonitoring assists with } \\
\text { decreasing the risk of patient self- } \\
\text { harm, and Safety Bundle of Best } \\
\text { Practices to decrease risk for patients } \\
\text { at risk for self-harm. }\end{array}$ & $>55 \%$ & $>90 \%$ & Continuous data \\
\hline Process Measure & $\begin{array}{l}\text {-Nurses and clinicians' compliance } \\
\text { with using the Columbia suicide } \\
\text { severity rating scale (C-SSRS) as a } \\
\text { first-line screening tool upon patient } \\
\text { arrival into the non-psychiatric unit } \\
\text { - Nurses and provider compliance } \\
\text { with education and training on the } \\
\text { use of C-SSRS tool. }\end{array}$ & $>50 \%$ & $>85 \%$ & Continuous data \\
\hline Process Measure & $\begin{array}{l}\text {-Clinicians and nurses' compliance } \\
\text { to timely administration of C-SSRS } \\
\text { upon patient arrival to the unit } \\
\text { - Nurses and clinicians' compliance } \\
\text { to the use of safety bundles. }\end{array}$ & $>50 \%$ & $>85 \%$ & Continuous data \\
\hline Balance Measure & $\begin{array}{l}\text {-Ensuring that suicidal ideations are } \\
\text { identified, and suicide behaviors do } \\
\text { not increase throughout patients' stay } \\
\text { in the non-psychiatric unit. }\end{array}$ & $>60 \%$ & $>90 \%$ & Continuous data \\
\hline Financial Measure & $\begin{array}{l}\text {-Cost of providing training, } \\
\text { education, overtime cost due to } \\
\text { training }\end{array}$ & $5 \%$ & $>90 \%$ & Continuous data \\
\hline Sustainability Measure & $\begin{array}{l}\text {-On-going education and training of } \\
\text { nurses and clinicians. }\end{array}$ & $85 \%$ & $>85 \%$ & Continuous data \\
\hline Sustainability Measure & $\begin{array}{l}\text {-Compliance with the use of the } \\
\text { screening tool in identifying at-risk } \\
\text { patients, and suicidal behavior. }\end{array}$ & $85 \%$ & $>85 \%$ & Continuous data \\
\hline & & & & \\
\hline
\end{tabular}




\section{Appendix L}

\section{Permission for CSSRS Tool}

From: Posner, Kelly (NYSPI) <kelly.posner@nyspi.columbia.edu>

To: Olayemi cynthia Akindele <olayemi.akindele@yahoo.com>

Cc: Posner, Kelly (NYSPI) <kelly.posner@nyspi.columbia.edu>; Paykina, Natalya (NYSPI)

<natalya.paykina@nyspi.columbia.edu>

Sent: Tuesday, August 4, 2020, 04:16:47 PM CDT

Subject: RE: Permission to use tool

Dear Researchers:

We are delighted that you are interested in using the C-SSRS in your research. You have permission to use scale for prospective monitoring of suicidal ideation and behavior in your non-sponsored research project. Below are the instructions for accessing the different versions of the scale and training. For additional information on the use of the scale in clinical trials and research studies, please refer to: http://cssrs.columbia.edu/the-columbia-scale-c-ssrs/cssrs-for-research/ For an up-to-date summary of representative studies, please consult our Summary of Evidence document.

Please feel free to contact us with additional questions.

Best wishes,

The Columbia Lighthouse Project 